\title{
QUALIDADE DO MEXILHÃO Perna perna SUBMETIDO AO PROCESSO COMBINADO DE COCÇÃO, CONGELAMENTO E ARMAZENAMENTO
}

\author{
DANIELA CORDEIRO
}

Dissertação apresentada à Escola Superior de Agricultura "Luiz de Queiroz", Universidade de São Paulo, para obtenção do título de Mestre em Ciências, Área de Concentração: Ciência e Tecnologia de Alimentos.

PIR A C I C A B A

Estado de São Paulo - Brasil

Julho - 2005 


\title{
QUALIDADE DO MEXILHÃO Perna perna SUBMETIDO AO PROCESSO COMBINADO DE COCÇÃO, CONGELAMENTO E ARMAZENAMENTO
}

\section{DANIELA CORDEIRO}

Zootecnista

Orientador: Prof ${ }^{\mathrm{a}}$. Dr ${ }^{\mathrm{a}}$. MARÍLIA OETTERER

\begin{abstract}
Dissertação apresentada à Escola Superior de Agricultura "Luiz de Queiroz", Universidade de São Paulo, para obtenção do título de Mestre em Ciências, Área de Concentração: Ciência e Tecnologia de Alimentos.
\end{abstract}

PIR A C I C A B A

Estado de São Paulo - Brasil

Julho - 2005 
Dados Internacionais de Catalogação na Publicação (CIP) DIVISÃO DE BIBLIOTECA E DOCUMENTAÇÃO - ESALQ/USP

\section{Cordeiro, Daniela}

Qualidade do mexilhão Perna perna submetido ao processo combinado de cocção, congelamento e armazenamento / Daniela Cordeiro. - - Piracicaba, 2005.

68 p. : il.

Dissertação (Mestrado) - - Escola Superior de Agricultura Luiz de Queiroz, 2005.

Bibliografia.

1. Análise de alimento 2. Bactéria patogênica 3. Conservação de alimento 4. Cozimento 5. Mexilhão 6. Microbiologia de alimento 7. Qualidade do alimento 8. Staphylococcus

9. Tratamento térmico I. Título

CDD 664.94

"Permitida a cópia total ou parcial deste documento, desde que citada a fonte - O autor" 
Ao meu pai Dercio (in memoriam), por sua presença mesmo distante. Às minhas avós Amélia (in memoriam) e Santina (in memoriam) por me transmitirem paz. Aos meus irmãos Junior e Dárcio Ao meu sobrinho Bruno, por existir na minha vida.

DEDICO

À minha mãe Dirce por sempre acreditar em mim.

OFEREÇO 


\section{AGRADECIMENTOS}

A Deus

À minha família pelo carinho e apoio, especialmente minha mãe, e os meus irmãos Junior, Darcio e Ingrid.

Ao meu sobrinho Bruno pela alegria que ele trouxe a minha família.

À minha orientadora, Prof ${ }^{a}$. Dr ${ }^{a}$. Marília Oetterer, pela amizade, orientação e incentivo para a realização deste trabalho.

À Escola Superior de Agricultura "Luiz de Queiroz" (ESALQ/USP), em especial ao Departamento de Agroindústria, Alimentos e Nutrição pela oportunidade para a realização deste trabalho.

À fundação de Apoio à Pesquisa do Estado de São Paulo (FAPESP) que financiou este trabalho.

À CAPES pela bolsa concedida.

Ao ITAL, que permitiu a realização do processamento em suas instalações.

Ao Dr Alfredo Vitalli pela colaboração na realização deste trabalho.

Aos estagiários e todos os funcionários do ITAL que ajudaram no processamento.

Especialmente à amiga Tatiana Gisele Guimarães Lopes, pelo companheirismo e momentos de risadas no decorrer deste trabalho.

Ao Prof Dr Ernani Porto pela colaboração, auxílio e paciência nas análises microbiológicas.

Aos estagiários , Luciana Kimie Savay da Silva, Anderson Giovanni Oliveira. 
Aos estagiários do laboratório de Microbiologia Mário, Bruna e Juliana.

Aos professores Drs Carmem Contreras, Solange Canniatti Brazaca e Severino Matias Alencar pelas sugestões e auxilio neste trabalho.

Aos funcionários do Departamento de Agroindústria, Alimentos e Nutrição, Cleomar, Lurdes, Débora, Maria Fernanda.

À Juliana Antunes Galvão, pois sem ela este trabalho não existiria.

À Érika Furlan, Viviane Angeli Yokayama e Lílian Marques Pino pelo auxilio no decorrer deste trabalho.

À Bibliotecária Beatriz Helena Giongo, pela correção deste trabalho.

Ao Marcelo Nascimento Baldo, pela amizade, compreensão e momentos de alegria.

À Roberta Claro da Silva, pela amizade em todos esses anos.

Às minhas amigas de República, Débora, Helena, Marina e Ana

Aos futuros pais Raquel, Conrado, Carol e André que sempre me apoiaram.

A todos os funcionários do Departamento de Agroindústria, Alimentos e Nutrição, que direta ou indiretamente colaboraram nesta pesquisa. 


\section{SUMÁRIO}

Página

LISTA DE FIGURAS ............................................................... viii

LISTA DE TABELAS ............................................................ ix

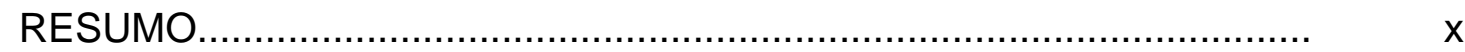

SUMMARY ................................................................................

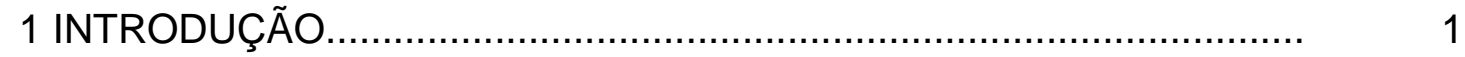

2 REVISÃO DE LITERATURA..................................................... 6

2.1 Aspectos bioquímicos....................................................... 6

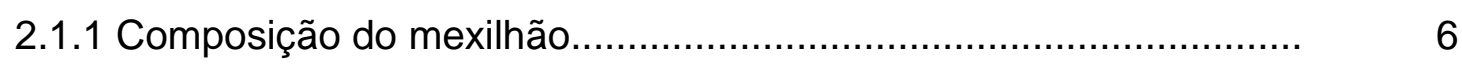

2.1.2 Padrões de qualidade...................................................... 7

2.1 .3 Oxidação lipídica ............................................................ 9

2.2 Microbiologia de moluscos..................................................... 10

2.3 Beneficiamento do mexilhão.................................................... 13

2.3.1 Cocção............................................................................... 13

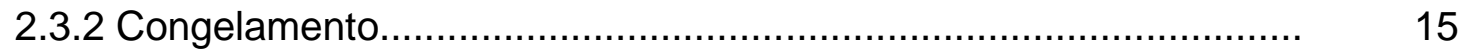

2.3.2.1 Métodos de congelamento............................................... 18

2.3.2.2 Velocidade de congelamento................................................... 20

2.3.2.3 Congelamento e microrganismos............................................. 21

2.3.3 Armazenamento sob congelamento.......................................... 24

3 MATERIAL E METÓDOS........................................................ 27

3.1 Matéria-prima.................................................................... 27

3.2 Coleta dos mexilhões......................................................... 27 
vii

3.3 Processamento dos mexilhões............................................ 27

3.3.1 Tratamento prévio - cocção............................................... 29

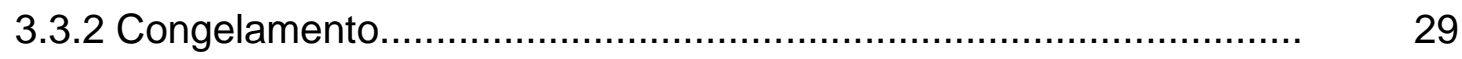

3.4 Cálculo da velocidade de congelamento e curva de congelamento... 34

3.5 Análises físico-químicas........................................................... 34

3.6 Análises microbiológicas..................................................... 34

3.6.1 Preparo das diluições..................................................... 34

3.6.2 Microrganismos analisados nas amostras de mexilhão................. 35

3.7 Análise estatística.................................................................. 35

4 RESULTADOS E DISCUSSÃO .............................................. 36

4.1 Curva de congelamento........................................................ 36

4.2 Velocidade de congelamento.................................................. 39

4.3 Análises físico-químicas............................................................ 40

4.3.1 Composição centesimal..................................................... 40

4.3.1.1 Umidade...................................................................... 41

4.3.1.2 Proteínas......................................................................... 42

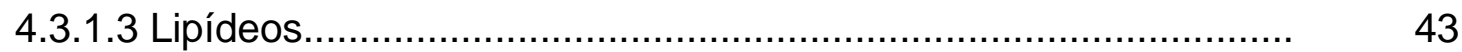

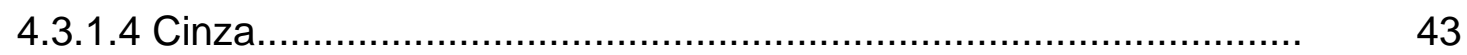

4.3.1.5 Carboidratos............................................................... 43

4.3.2 Padrões de qualidade...................................................... 44

4.3.2.1 BNVT e TMA........................................................... 44

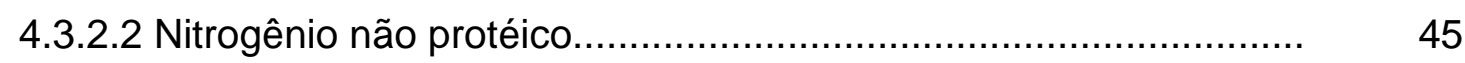

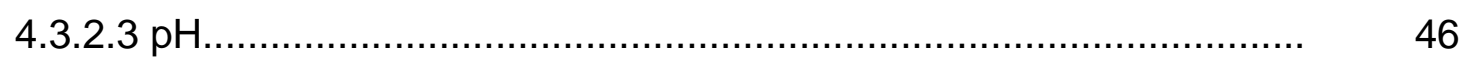

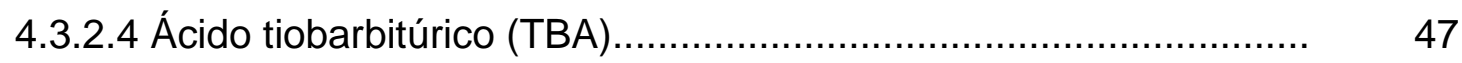

4.4 Análises microbiológicas....................................................... 48

5 CONCLUSÕES............................................................... 53

REFERÊNCIAS BIBLIOGRÁFICAS .............................................. 54 


\section{LISTA DE FIGURAS}

Página

1 Fluxograma de processamento e análises do mexilhão....................... 28

2 Desconchamento dos mexilhões.............................................. 30

3 Distribuição nas bandejas....................................................... $\quad 30$

4 Bandejas para congelamento em IQF......................................... 31

5 Distribuição dos termopares nas bandejas....................................... 31

6 Câmara de congelamento....................................................... 32

7 Software E-Vail Basic......................................... 32

8 Embalamento dos mexilhões................................................... 33

9 Mexilhões semi-desconchados................................................ 33

10 Curva de congelamento dos mexilhões alojados na parte superior do congelador próximo ao circulador.................................................. 37

11 Curva de congelamento dos mexilhões alojados na parte superior do congelador próximo a porta......................................................... 37

12 Curva de congelamento dos mexilhões alojados na parte inferior do congelador próximo ao circulador. 


\section{LISTA DE TABELAS}

Página

1 Tempo e velocidade de congelamento dos mexilhões....................... 39

2 Composição centesimal dos mexilhões in natura, processados e armazenados congelados

3 BNVT e TMA dos mexilhões in natura, processados e armazenados congelados.

4 NNP e pH dos mexilhões in natura, processados e armazenados congelados.

5 TBA dos mexilhões in natura, processados e armazenados congelados.

6 Microrganismos em mexilhões in natura, processados e armazenados congelados. 


\title{
QUALIDADE DO MEXILHÃO Perna perna SUBMETIDO AO PROCESSO COMBINADO DE COCÇÃO, CONGELAMENTO E ARMAZENAMENTO
}

\author{
Autora: DANIELA CORDEIRO \\ Orientadora: Prof ${ }^{\mathrm{a}}$. Dr ${ }^{\mathrm{a}}$. MARÍLIA OETTERER
}

\section{RESUMO}

Os mexilhões cultivados no litoral Norte de São Paulo, município de Ubatuba, são comercializados in natura, constituindo risco à população. Com o crescimento da atividade é possível sugerir a implantação de uma unidade de processamento de mexilhões que promova um aumento do tempo de armazenamento, facilitando a comercialização e permitindo a exportação, além de fornecer ao consumidor um produto de melhor qualidade. Os mexilhões foram submetidos ao processamento por cocção, congelamento e armazenamento, sendo então determinados o ponto de congelamento, a velocidade de congelamento a as curvas de congelamento do mexilhão semidesconchado. A qualidade microbiológica e físico-química do produto foi avaliada. O beneficiamento do mexilhão iniciou-se com a cocção por imersão em água à ebulição por 10 minutos. Após a retirada das conchas, os mexilhões foram congelados individualmente IQF (Individually Quick Frozen) a $-20^{\circ} \mathrm{C}$ e armazenados $\mathrm{a}-18^{\circ} \mathrm{C}$ durante 90 dias. A curva de congelamento do mexilhão apresentou forma geral típica, com o ponto de congelamento situando-se na 
faixa de zero a $-1,5^{\circ} \mathrm{C}$; a velocidade de congelamento variou de $2 \mathrm{~cm} / \mathrm{h}$ a 3,3 cm/h, conforme a disposição dentro da câmara de congelamento. Os resultados físico-químicos mostraram que não houve diferença significativa no valor nutricional dos mexilhões in natura, processados e armazenados, apresentando os teores médios de 7,4mg/100g de proteínas, 5,8 mg/100g de carboidratos e 1,4 mg/100g de lipídeos. Os valores encontrados para BNVT, TMA e pH no mexilhão in natura foram, 4,3 mg/100g; 2,0 mg/100g e 6,2 , respectivamente, estando dentro dos limites estipulados pela legislação de 30mg/100g para BNVT e $4 \mathrm{mg} / 100 \mathrm{~g}$ de TMA. Após o processo de cocção e congelamento houve um aumento no valor do $\mathrm{pH}$ para 6,9, enquanto o BNVT manteve-se na média. Todas as amostras de mexilhão in natura atenderam aos padrões microbiológicos estabelecidos pela legislação (RDC, n¹2 de 02 de janeiro de 2001). Salmonella sp e Vibrio parahaemolyticus não foram isoladas em nenhuma das amostras de mexilhões in natura, cozidos, congelados e armazenados. O tratamento térmico foi efetivo no controle dos coliformes fecais, redução de coliformes totais, Staphylococcus coagulase+ e psicrotróficos. O processo de congelamento reduziu a contagem de coliformes totais e Staphyloocccus coagulase+, mantendo-se inalterados durante o armazenamento a $-18^{\circ} \mathrm{C}$ por 90 dias. Concluiu-se que o beneficiamento do mexilhão pelo processo combinado de cocção, congelamento e armazenamento assegura a qualidade físico-química e microbiológica do produto, podendo ser adotado como padrão para industrialização. 


\title{
THE QUALITY OF THE MUSSEL (Perna perna) PROCESSING BY COOKING, FREEZING AND STORAGE
}

\author{
Author: DANIELA CORDEIRO \\ Adviser: Prof ${ }^{\mathrm{a}}$. Dr ${ }^{\mathrm{a}}$. MARÍLIA OETTERER
}

\section{SUMMARY}

The mussels cultivated in the coast North of São Paulo, city of Ubatuba, are commercialized in natura, constituting risk to the population. With the growth of the activity it is possible to suggest the implantation of a unit of mussel processing that promotes an increase of the storage time, facilitating the commercialization and allowing the exportation, besides supplying to the consumer a product of better quality. The mussels had been submitted to the processing for cooking, freezing and storage, being then determined the freezing point, the speed of freezing to the curves of freezing of the semidesconchado mussel. The microbiological quality and physicochemical of the product were evaluated. The processing of the mussel was started with the immersion in boiling water per 10 minutes. After the withdrawal of the shells, the mussels had been frozen individually IQF (Individually Quick Frozen) at $-20^{\circ} \mathrm{C}$ and stored at $-18^{\circ} \mathrm{C}$ during 90 days. The curve of freezing of the mussel presented typical general form, with the freezing point placing from zero to $-1,5^{\circ} \mathrm{C}$; the freezing speed varied from $2 \mathrm{~cm} \cdot \mathrm{h}^{-1}$ to $3,3 \mathrm{~cm} \cdot \mathrm{h}^{-1}$, as the disposal 
inside of the freezing chamber. The physicochemical components had not shown significant difference in the nutricional value of mussels in natura, processed and stored, presenting $7.4 \mathrm{mg} .100 \mathrm{~g}^{-1}$ of proteins, $5.8 \mathrm{mg} .100 \mathrm{~g}^{-1}$ of carbohydrates and $1.4 \mathrm{mg}^{100 \mathrm{~g}^{-1}}$ of lipids. The values found for BNVT, TMA and $\mathrm{pH}$ in the mussel in natura had been, $4.3 \mathrm{mg} 100 \mathrm{~g}^{-1} ; 2,0 \mathrm{mg}^{-100 \mathrm{~g}^{-1}}$ and 6.2 , respectively, being inside of the limits stipulated for the legislation of $30 \mathrm{mg} \cdot 100 \mathrm{~g}^{-1}$ for BNVT and $4 \mathrm{mg} \cdot 100 \mathrm{~g}^{-1}$ of TMA. After the process of cooking and freezing had an increase in the value of $\mathrm{pH}$ for 6.9 , while the BNVT was remained in the average. All the mussel samples in natura had taken in concordance of the microbiological standards established by the legislation (RDC, $\mathrm{n}^{0} 12$ January, $2^{\text {nd }}$, 2001). Salmonella sp and Vibrio parahaemolyticus had not been isolated in none of the fresh mussel samples, cooked, frozen and stored. The thermal treatment was effective in the control of the fecal coliformes, reduction of total coliformes, Staphylococcus coagulase+ and psychrotrophics. The freezing process reduced the counting of total coliformes and Staphyloocccus coagulase + , remaining unchanged during the storage $-18^{\circ} \mathrm{C}$ per 90 days. The processing of the mussel through the cooking, freezing and storage assures the microbiological, and physicochemical quality of the product, wich can be addoted as standard for the industry. 


\section{INTRODUÇÃO}

Atualmente a aqüicultura é uma importante fonte produtora de proteína animal em várias regiões do mundo. Segundo a FAO (2003) a atividade apresenta um contínuo aumento na contribuição do volume da produção pesqueira, passando de 5,3\% em 1970 para 32,2\% em 2003. Este crescimento da aqüicultura supera em termos percentuais vários outros setores de produção animal. Desde 1970, a aqüicultura vem apresentando um crescimento anual de 8,9\%, sendo muito superior ao crescimento da indústria pesqueira oriunda da captura $(1,4 \%)$ e aos sistemas de produção de proteína terrestre (2,8\%), no mesmo período (Scorvo Filho, 2004).

A Espanha e a França produzem cerca de 300.000 t/ano de mexilhões cultivados. A Espanha é a maior produtora mundial, principalmente devido às características ecológicas da região e ao baixo custo da mão de obra. O mexilhão cultivado nessa região é o Mytilus galloprovincialis, com uma produção de cerca de 250.000 t/ano. Na França, cria-se o mexilhão azul, M. edulis, sendo produzidas ao redor de 50.000 t/ano. O mexilhão Perna canaliculus, cultivado na Nova Zelândia, pelo método do "long line" atinge a cifra de produção de 30.000 t/ano, das quais uma parte é exportada para o Japão, Estados Unidos e Austrália (Lunetta, 2002).

No Brasil, a aqüicultura também vem despontando como atividade promissora, registrando um crescimento superior à média mundial, passando de 20.500 t em 1990, para 210.000 t em 2001, neste período o Brasil obteve um crescimento de aproximadamente $925 \%$, enquanto a aqüicultura mundial teve 
um crescimento de $187 \%$ no mesmo período. O resultado desse crescimento fica evidenciado no ranking mundial estabelecido pela FAO, onde o Brasil encontrava-se na 36 ${ }^{\mathrm{a}}$ colocação em 1990 e passou a ocupar a 19a posição em 2001. No ranking da América do Sul o Brasil encontra-se em segundo lugar com 210.000 t, superado apenas pelo do Chile com $631.600 \mathrm{t}$ (Scorvo Filho, 2004).

A malacocultura que envolve a produção de moluscos (ostras, mexilhões e vieiras) produziu em 2000, um total de $12.500 \mathrm{t}$, sendo os principais estados produtores Santa Catarina, São Paulo e Rio de Janeiro produzindo, respectivamente, $12.259 \mathrm{t}, 127 \mathrm{t}$ e $9 \mathrm{t}$, segundo dados do Departamento de Pesca (Ibama, 2005).

Segundo Borghetti \& Ostrensky (2000), os moluscos produzidos no Brasil são mexilhão Perna perna, duas espécies de ostras, a nativa Crassostrea rhizophorae e a ostra do Pacifico Crassostrea gigas, além de uma espécie de Vieira Nodipecten nodosus.

Brandini et al. (2000) afirmaram que o cultivo de moluscos filtradores em águas brasileiras tem um bom potencial, pois o litoral brasileiro possui baías, enseadas e regiões estuarias-lagunares.

O cultivo de moluscos bivalves, vem se consolidando de maneira expressiva, principalmente, em Santa Catarina. Com um crescimento de $37,7 \%$ em 2001, a atividade está concentrada, principalmente, no cultivo de mexilhões e ostras. Estima-se que mais de mil produtores se dedicam, atualmente, à produção de ostras e mexilhões em Santa Catarina, com geração de 2,1 mil empregos diretos e outros 6,3 mil indiretos. A área total de criação chega a 900 ha, divididos em 12 parques aqüícolas. Os produtores estão organizados em 18 associações regionais e duas estaduais. No caso das ostras, a produção do Estado alcançou 1,7 milhão de dúzias em 2003, um incremento de 7\% em relação a 2002. A Moluskus, Fazenda Marinha de Palhoça em Santa Catarina produz, atualmente, cerca de 7 mil dúzias de ostras mensais. Em 2003, a empresa produziu $70.000 \mathrm{t}$ de mexilhão (Pacheco, 2004). 
A industrialização do produto catarinense ainda não é realizada no Estado. Até o presente, o processamento dos mexilhões é realizado de forma artesanal, normalmente em ranchos, com estruturas improvisadas, via de regra, sem condições ideais de higiene que permitam assegurar qualidade ao produto. No sistema atual de comercialização e distribuição dos moluscos, prevalece ainda a venda do produto in natura ou desconchado, nas proporções de $30 \%$ a $70 \%$, respectivamente. Do desconchado, metade é vendida a granel e os outros $50 \%$ são embalados em sacos plásticos (Pacheco, 2004).

No estado de São Paulo, a produção de mexilhões no Litoral Norte, Ubatuba, é considerada também uma atividade economicamente viável no âmbito da produção familiar, praticada essencialmente em sistemas flutuantes inspirados nas balsas e "long lines". Cada sistema simples produz até duas toneladas de mexilhão sem casca por safra, em períodos entre 6 e 9 meses. Em 1994, existiam nove parques de criação ao longo do litoral norte. Atualmente, a produção em média é de 100 t/ano, envolvendo cerca de 90 produtores. Além das ações de desenvolvimento e transferência de tecnologia, o Instituto de Pesca atua no ordenamento da mitilicultura, através do mapeamento e cadastramento de áreas propícias, visando a sustentabilidade da atividade e à minimização dos conflitos de utilização de áreas públicas. (Simões, 2005).

A atividade está em crescimento, porém apresenta problemas organizacionais. Na região não há um entreposto que receba a produção e nem um ponto de beneficiamento. O SIF - Serviço de Inspeção Federal do Ministério de Agricultura Pecuária e Abastecimento não contempla área de cultivo e sim estabelecimento, o que faz com que o produtor não possa transportar o seu produto legalmente para outros mercados consumidores. Sem fiscalização há conseqüente risco à saúde pública. A clandestinidade inviabiliza a comercialização com marketing, mantendo a demanda baixa até mesmo na região litorânea (Assumpção, 1999). 
Segundo dados do Ministério da Agricultura, Pecuária e Abastecimento - MAPA, o Brasil em 1998 importou 550 t de mexilhão (principalmente da Espanha, Nova Zelândia e Chile), sem exportar um quilo sequer. Enquanto isso, o Chile exportou no mesmo ano $700 \mathrm{t}$ com um valor de US\$1,98 milhões (Brasil, 2004).

Em alguns casos, o preço do mexilhão importado se iguala aos preços do produto nacional. A vantagem alegada pelos importadores é a de que o produto importado apresenta uma qualidade superior, caracterizada por uma certificação sanitária de reconhecimento internacional (HACCP Hazard Analysis and Critical Control Point), tamanho padronizado, embalagem apropriada e oferta regular. O produto importado é apresentado na forma de carne congelada individualmente (IQF) com qualidade sanitária internacionalmente referendada (HACCP). Para que o produto nacional chegue a este mesmo nível de qualidade, estima-se a adição de um custo de processamento (congelamento e embalagem) de aproximadamente $U \$ 0.41 / \mathrm{Kg}$ ao preço do nosso produto, chegando a um preço final de U\$2.21, sem considerar a incidência de impostos (Brasil, 2004).

O valor agregado em produtos provindos da piscicultura, não deve necessariamente estar vinculado à elaboração de produtos sofisticados e modernos, e sim prioritariamente à qualidade intrínseca do pescado ou matériaprima utilizada. O investimento em qualidade é considerado o grande diferencial de um produto ou marca, na atualidade. A piscicultura propicia um alto nível de controle de qualidade, sobre o peixe processado, pois o intervalo de tempo entre a despesca e o abate, e entre a morte do animal e a conservação do produto processado são relativamente curtos, podendo ser processado em poucos minutos (Neiva, 2003).

O tipo de conservação utilizada irá definir o tempo de vida útil ou de conservação do produto. Entretanto, esta conservação deve ser tal, que o alimento conserve ao máximo suas qualidades sensoriais e nutritivas, como também a segurança para o consumo (Neiva, 2003). 
Esta pesquisa teve o objetivo de submeter os mexilhões ao processamento por congelamento e posterior armazenamento congelado. Assim, as etapas de cocção prévia, desconchamento, embalamento e congelamento foram estabelecidas (padronizadas), através das análises de qualidade para comercialização, conforme exigências da legislação. Esta pesquisa é parte do projeto de políticas públicas designado de "Diagnóstico e intervenções emergentes para comercialização de pescado - mexilhões no Litoral norte, região de Ubatuba, SP, para implantação de beneficiadora de mexilhões". 


\section{REVISÃO DE LITERATURA}

\subsection{Aspectos bioquímicos}

\subsubsection{Composição do mexilhão}

A composição da parte comestível de peixes, crustáceos e moluscos varia entre 70 a $85 \%$ de umidade, 20 a $25 \%$ de proteínas, 1 a $10 \%$ de lipídeos, 0,1 a $1,0 \%$ de carboidratos e 1 a 1,5\% de cinza. Essa composição é altamente variável de espécie para espécie. As ostras e os mariscos são incluídos no grupo que apresenta baixos teores de lipídeos e de proteínas, isto é, com valores menores que 5\% para lipídeos e 15\% para proteínas; caraterizam-se por apresentar quantidades elevadas de glicogênio (Beirão, 2000).

O mexilhão apresenta pronunciada variação sazonal na composição de sua carne, com maior rendimento na época de desova. O valor energético da sua carne é de $80 \mathrm{Kcal} / 100 \mathrm{~g}$, próximo ao dos peixes magros como a merluza (Merlucius merlucius) enquanto que outros moluscos e ostras apresentam em média, respectivamente, $76 \mathrm{Kcal} / 100 \mathrm{~g}$ e $44 \mathrm{Kcal} / 100 \mathrm{~g}$. Possuem 1 a $7 \%$ de glicogênio, teor elevado em relação às outras carnes e peixes, onde este carboidrato se encontra em baixa proporção. A fração protéica do pescado situa-se na faixa de $8,4 \%$ a $17 \%$; já para mariscos e ostras os valores médios são de $13 \%$ e $6 \%$, respectivamente (Silva, 2000).

Os lípideos dos produtos marinhos são altamente insaturados. Em estado inalterado constituem excelente fonte calórica e não acarretam elevação dos níveis de colesterol sangüíneo. Entretanto, o elevado índice de insaturação 
os deixam suscetíveis à oxidação, podendo se tornar rapidamente rançosos, especialmente quando se elaboram produtos salgados e secos. Este fato não apenas diminui a qualidade, mas também acarreta riscos, devido ao teor de peróxidos resultante da oxidação lipídica (Beirão, 2000).

Furtado et al. (1998), analisaram sururu (Mytella falcata) e berbigão (Anomalocardia brasiliana) e concluíram que a espécie Mytella falcata apresentou teores médios de umidade de 30,65\% e proteína de 56,44\%, enquanto que para a espécie Anomalocardia brasilian, os teores foram 25,62\% e 48,14\%, respectivamente. O teor de lipídeos mostrou-se menor no molusco Mytella falcata com média de 2,9\% enquanto o Anomalocardia brasiliana expressou um valor superior com média de 7,7\% e também apresentou-se mais rico nos teores de cinza $(3,13 \%)$ e carboidratos $(15,18 \%)$ ao passo que a espécie Mytella falcata revelou um teor médio de 1,38\% e 8,45\% destes componentes, respectivamente. Quanto aos minerais, o zinco apresentou teores de maior expressão: 70,5 mg para $M$. falcata e 68,8 mg para $A$. brasiliana. A quantidade média de cálcio encontrada para o $M$. falcata foi de $53,7 \mathrm{mg}$ e para o $A$. brasiliana $49,5 \mathrm{mg}$, comprovando assim a importante colaboração destes bivalves como fontes de nutrientes na alimentação de populações litorâneas.

\subsubsection{Padrões de qualidade}

Os padrões de qualidade do pescado e derivados estão baseados na análise de compostos como Bases Voláteis Totais (BNVT) e Trimetilamina (TMA), segundo o Ministério da Agricultura que regulamenta o R.I.I.S.P.O.A Regulamento de Inspeção Industrial e Sanitária de Produtos de Origem Animal (Brasil,1980) e preconiza níveis de Bases Voláteis Totais como inferiores a 30 mg N/100g em carnes para atestar frescor ao produto; para $\mathrm{pH}$ os níveis aceitáveis devem ser inferiores a 6,8 na parte externa e 6,5 na parte interna da carne. Determinam frescor também, a reação negativa para gás sulfídrico e 
indol, com exceção de alguns crustáceos onde o limite é de no máximo 4 mg N/100g. Substâncias nitrogenadas não protéicas como inosina, ribose, uréia, e óxidos de trimetilamina de baixo peso molecular, são resultantes da ação enzimática no músculo do pescado, constituindo-se em substratos preferenciais para a utilização e decomposição microbiana, responsáveis por profundas alterações organolépticas no pescado (Beirão et al., 2000; Pregnolatto \& Pregnolatto, 1985).

O pescado apresenta sua flora microbiana normal que, somada à que se instala pela manipulação, constituem o principal agente de deterioração da matéria-prima (Beirão, 2000).

A ação microbiana sobre OTMA (óxido de trimetilamina) e TMA (trimetilamina) modifica sensivelmente a concentração destes compostos. OTMA age como um receptor de elétrons na respiração e produz TMA. Esta última tem odor característico de pescado que perdeu parte do seu frescor. OTMA também se decompõe no músculo dando DMA (dimetilamina) e formaldeido (Beirão, 2000).

O TMA existe nos peixes e invertebrados marinhos. Este composto existe em quantidade variável nas diferentes espécies sendo particularmente elevado nos cações (Carcharrhinus spp) e arraias (Potamotrygon spp), nos quais atinge até $1.500 \mathrm{mg} / 100 \mathrm{~g}$. Na corvina (Plagioscion spp), pescada (Cynoscion sp), pargo (Pagrus pagrus) e outros peixes de carne branca também apresenta-se com elevados valores entre 200 e $300 \mathrm{mg} / 100 \mathrm{~g}$. No atum (Tunnus spp) encontra-se quantidades abaixo de $20 \mathrm{mg} / 100 \mathrm{~g}$, porém nos peixes de parentesco próximo, como bonito (Euthynnus alleteratus) e cavalinha (Scomber japonicus), os teores de TMA estão entre 20 e 60 mg/100g. Apenas uma pequena fração do OTMA se torna TMA durante o período de vida útil do pescado no gelo e esta quantidade depende não apenas do teor de OTMA mas, também, das condições de manuseio e conservação (Contreras-Guzman, 1982). 


\subsubsection{Oxidação lipídica}

A oxidação lipídica é um processo que colabora para a perda de qualidade da carne e seus produtos (Gray et al., 1996).

A fração lipídica dos alimentos está relacionada a diversas propriedades organolépticas como aroma, cor textura, suculência, estabilidade das proteínas, vida útil sob congelamento e conteúdo calórico (Allen \& Foegeding, 1981).

As reações oxidativas de ácidos graxos dão origem à formação de aldeídos e outros compostos voláteis que conferem odores desagradáveis a produtos cárneos e derivados, armazenados. Estes produtos apresentam aroma e sabor de "alimento requentado", bem como promovem a modificação da cor, quando há transformação do pigmento oximioglobina em metamioglobina. Outro aspecto importante diz respeito a alteração da textura da carne, advinda da oxidação lipídica, uma vez que esta pode resultar na formação de complexos proteína-lipídios ou provocar cisão das proteínas (Kanner, 1994).

Os hidroperóxidos formados durante o processo de oxidação lipídica são essencialmente inodoros, contudo, eles se decompõem em uma grande variedade de compostos secundários voláteis e não-voláteis. Dentre estes, os aldeídos são os que mais contribuem para perda do aroma natural das carnes, devido à sua facilidade de formação durante o processo de oxidação lipídica. De uma maneira geral, o dor desenvolvido nas carnes armazenadas sob refrigeração pode ser atribuído mais ao mascaramento do seu aroma natural, resultando no aumento do conteúdo de odores desagradáveis no material armazenado, do que pela degradação do aroma original (Gray et al., 1996).

Um dos métodos mais utilizados, em produtos cárneos, para se avaliar a extensão da estabilidade lipídica é o teste de TBA (ácido 2-tiobarbitúrico), visto que produtos primários de oxidação lipídica constituem-se principalmente de hidroperóxidos, os quais são rapidamente decompostos em 
várias substâncias reativas ao ácido 2-tiobarbitúrico (TBA), particularmente carbonilas, sendo o malonaldeido o elemento mais importante. O produto da reação destas substâncias com o TBA é colorido e absorve fortemente em 532nm (Tarladigs et al.,1960).

A oxidação também pode ocorrer em função da atividade de água (Aa) do produto, propriedade de um alimento que pode ser definida como a água disponível para o crescimento microbiano ou demais reações de natureza química, física ou enzimática. Para os alimentos, em geral, com valores menores que 0,6 de atividade de água, a intensidade de deterioração é mais baixa, sendo cada vez menor à medida que este valor diminui. No entanto, a susceptibilidade de carnes congeladas à oxidação se deve à Aa. Enquanto que a carne fresca possui uma $\mathrm{Aa}$ de 0,99 , durante o congelamento a $-18^{\circ} \mathrm{C}$, a $\mathrm{Aa}$ pode ser reduzida a valores de até 0,6 . A Aa na faixa de 0,8 a 0,6 favorece o aumento das reações de oxidação lipídica (Van Laack, 1994).

Os alimentos perecíveis são os que oferecem maior disponibilidade de água para o crescimento microbiano. A redução da atividade de água é, portanto, fator preponderante na preservação de alimentos. Em geral, afirma-se que ao se reduzir a atividade de água a 0,85 para 0,65 , a vida útil aumenta de uma semana para dois anos, desde que o produto seja devidamente embalado, de modo a manter a atividade de água constante ao longo da armazenagem (Labuza, 1982).

Os perigos alimentares de ingestão de lipídeos de pescado oxidados são devidos aos peróxidos e reações que possam ocorrer no organismo humano. Em geral, o efeito nocivo dos óleos de pescado oxidados refletem danos secundários devidos à formação de radicais livres a partir da decomposição dos peróxidos, tendo os radicais livres capacidade de destruir as vitaminas A e E (Beirão, 2000).

\subsection{Microbiologia dos moluscos}


O ecossistema aquático representa uma fonte de recursos naturais, favorecendo o cultivo de mexilhões, animais micrófagos que se alimentam de partículas e microrganismos em suspensão na água. O nível de absorção de nutrientes depende da temperatura, salinidade e salubridade do meio ambiente de cultivo ou extração dos mexilhões. Dessa forma, seu consumo pode representar risco para o homem quando oriundos de áreas poluídas ou contaminadas (West, 1989).

A qualidade dos moluscos bivalves, especialmente ostras e mexilhão, está diretamente relacionada com a qualidade dos ambientes onde são cultivados ou extraídos (Wood, 1979).

A contagem de microrganismos viáveis em crustáceos e moluscos refere-se geralmente ao animal inteiro ou a carne separada da concha; geralmente alcançam populações entre $10^{3}$ e $10^{7}$ UFC/g. Existe uma relação estabelecida entre cargas microbianas altas ou baixas e a procedência dos animais de águas frias ou quentes. Os moluscos, devido ao seu tipo de vida sedentária, apresentam contagens bacterianas que refletem o estado microbiológico das águas de cultivo, podendo ser observadas variações sazonais cujas contagens aumentam nos meses de verão (ICMSF, 1988; Jay, 1994).

As ostras e outros moluscos filtradores, através dos quais passam grandes quantidades de água, recolhem desta forma os microrganismos da água, inclusive patógenos ali existentes. Nesses alimentos marinhos se encontram espécies do gênero Alcaligenes, Flavobacterium, Moraxella, Acinetobacter e algumas bactérias Gram positivas (ICMSF, 1988; Jay, 1994).

A predominância de certas espécies de bactérias que alteram o pescado depende da temperatura de armazenagem; no caso da refrigeração, predominam as espécies de Pseudomonas, Shewanella, Acinetobacter, Moraxella e Flavobacterium (Frazier \& Westhoff, 1993; Jay, 1994).

O pescado é altamente perecível em condições normais de manuseio e armazenagem. A deterioração ocorre principalmente por 
microrganismos que encontram nos tecidos marinhos um substrato altamente nutritivo. Juntamente com a deterioração microbiológica, porém em um plano de importância secundária, ocorrem alterações bioquímicas e químicas de origem autolíticas. Após a morte, estas reações degradam componentes do próprio músculo, quebrando as macromoléculas de proteínas, gorduras, carboidratos e ácidos nucléicos a compostos menores. Como resultado de todos estes fenômenos, os músculos tornam-se progressivamente moles e em casos extremos, podem chegar até sua liquefação. Paralelamente, são produzidos compostos com odores indesejáveis, próprios de putrefação (ContrerasGuzman,1982).

Vários microrganismos, principalmente da família Enterobacteriaceae, como coliformes totais, coliformes fecais e Escherichia coli, têm sido utilizados com indicadores da qualidade sanitária das águas de cultivo e dos moluscos bivalves (Martinez-Manazares et al., 1991; Son \& Fleet, 1980).

A possibilidade de transmissão para humanos, de bactérias patogênicas de origem entérica procedentes de águas residuais, incluindo a Salmonella sp, via moluscos, tem sido relatada há muito tempo. É possível assumir, a priori, que sorotipos de Salmonella sp encontrados em águas marinhas poluídas por esgotos domésticos seriam derivados de infecções humanas (ICMSF, 1988).

Um certo número de doenças ocasionadas por moluscos bivalves, também tem sido associada com bactérias do gênero Vibrio, microrganismos aquáticos de vida livre, habitantes de águas estuarinas e marinhas. Entre as espécies marinhas classificadas como patogênicas encontram-se o Vibrio cholerae, Vibrio parahaemolyticus e Vibrio vulnificus. Em geral, as doenças diarréicas causadas por Vibrio parahaemolyticus originadas por moluscos bivalves aparecem nas zonas costeiras durante o verão e diminuem quando a temperatura da água se eleva (Antoniolli, 1999).

É possível a eliminação de bactérias do gênero Vibrio em moluscos bivalves, a partir de processo de cocção, através do consumo rápido ou 
armazenamento a altas temperaturas $\left(60^{\circ} \mathrm{C}\right)$ ou baixas temperaturas $\left(4^{\circ} \mathrm{C}\right)$, evitando a contaminação cruzada depois do desconchamento (Antoniolli, 1999).

Os estafilococos são bactérias mesófilas que apresentam temperaturas de crescimento na faixa de $7^{\circ} \mathrm{C}$ a $47,8^{\circ} \mathrm{C}$, com produção de enterotoxinas, entre $10^{\circ} \mathrm{C}$ e $46^{\circ} \mathrm{C}$, responsáveis pela incidência de surtos de intoxicações alimentares, provocados por alimentos que permanecem neste intervalo de temperatura critica (Franco \& Landgraf, 1996).

O Staphylococcus aureus é freqüentemente pesquisado em alimentos processados. Alimentos, que em geral estão envolvidos em intoxicações estafilocócicas, são os que apresentam elevado teor protéico, altas concentrações de sal ou foram termicamente processados, e posteriormente contaminados por manipuladores (Bryan, 1973).

\subsection{Beneficiamento do mexilhão}

A armazenagem e estocagem dos moluscos são limitadas se comercializados in natura, as valvas ocupam muito espaço dificultando o armazenamento e quando há beneficiamento, este é feito em uma parcela pequena da matéria-prima. A tendência é de se promover o incremento da capacidade de armazenamento e estocagem destes produtos, buscando adequá-los aos novos processos de beneficiamento, garantindo a qualidade que o mercado exige (Beirão et al., 2000).

\subsubsection{Cocção}

O beneficiamento do mexilhão é iniciado com a cocção que permite a retirada das conchas e a ligeira pasteurização da carne. Após lavagem, o mexilhão é cozido durante 6 minutos, em água à ebulição ou vapor a $100^{\circ} \mathrm{C}$, ou por 4 minutos, em vapor a $115^{\circ} \mathrm{C}$. Após cocção e descasque, a carne pode ser 
resfriada e empacotada para ser comercializada ou destinada à industrialização (Espínola \& Dias, 1980).

O tratamento térmico é recomendado para melhorar a conservação dos alimentos, uma vez que inativa o crescimento das bactérias, parasitas e vírus patogênicos $\mathrm{Na}$ cocção, os moluscos bivalves são expostos ao calor úmido por um tempo que varia de acordo com o tamanho do marisco, velocidade de penetração do calor e as condições de aquecimento (Wood, 1973).

Levando em consideração as condições mais criticas de contaminação, desde a recepção até o consumo, a temperatura ideal de cocção no interior dos alimentos deve ser de $74^{\circ} \mathrm{C}$ por 5 min. ou $65^{\circ} \mathrm{C}$ por $10 \mathrm{~min}$. (Silva Junior, 1995)

Em estudo realizado por Antoniolli (1999) sobre a vida útil de mexilhões Perna perna processados e mantidos sob refrigeração, utilizando diferentes tempos de cocção, de 15 a $30 \mathrm{~min}$, com temperaturas finais variando de 80 a $96^{\circ} \mathrm{C}$, foi observado que todos os tratamentos aplicados foram eficazes na eliminação dos microrganismos, sendo que o tratamento térmico de $30 \mathrm{~min}$, atingindo temperatura final de $96^{\circ} \mathrm{C}$, apresentou melhores características sensoriais, e facilitou o processo de desconchamento dos mexilhões.

Salan (2005) testando o tratamento térmico de mexilhões Perna perna como forma de assegurar a qualidade, avaliando o crescimento de Bacillus cereus e de Staphylococcus aureus, verificou que tanto o tratamento térmico sob vapor (5, 10 e $15 \mathrm{~min}$ ) como por imersão em água (5,10 e15 min), foram eficientes eliminado os microrganismos da ordem de pelo menos 2 ciclos logarítmicos, sendo que, o tratamento térmico, binômio tempo-temperatura, de 10 min imersão em água à ebulição, é suficiente para reduzir os microrganismos, permitindo a retenção dos nutrientes e um rendimento de $54,36 \%$.

Segundo Pereira et al. (2004) que estudou Aeromonas spp e Plesiomonas shigelloides isoladas a partir de mexilhões (Perna perna) in natura 
e pré-cozidos, verificou que o efeito da temperatura de pré-cozimento (processo de aquecimento em vapor d'água por aproximadamente 3 min.) dos mexilhões, revelou-se efetivo em alguns casos, levando à diminuição de algumas espécies patogênicas como $A$. hydrophila, A. sóbria, $A$. veronii biogrupo veronni e A. trota., portanto, o processo tecnológico de pré-cocção permitiu diminuir a carga inicial presente no alimento. Esse procedimento tende a minimizar os riscos da contaminação do produto que logo em seguida à pré-cocção será beneficiado, congelado e mantido em temperatura inferior $\mathrm{a}-18^{\circ} \mathrm{C}$.

Há possibilidades de problemas referentes à manutenção do binômio tempo/temperatura durante a fase de pré-cocção, ou talvez recontaminação do produto após esta fase. Portanto, a etapa de pré-cocção deverá ser bem realizada a fim de reduzir a carga microbiana dos mexilhões in natura. A adoção de Boas Práticas de Manufatura pode auxiliar na diminuição da ocorrência de contaminação cruzada ou recontaminação dos mexilhões pré-cozidos (Kirov et al., 1993).

\subsubsection{Congelamento}

Dentre os alimentos frescos, o pescado e outros produtos marinhos como mexilhões, ostras e crustacéos são de fácil deterioração. Estes produtos são facilmente perecíveis, porque suas vísceras contêm grande número de microrganismos, e seus componentes, incluindo proteínas e lipídeos, são facilmente decompostos. Os produtos marinhos devem ser rapidamente refrigerados logo após captura e prontamente consumidos ou processados. Para um longo período de estocagem estes produtos devem ser então congelados (Beirão, 2000).

O uso do frio como método de preservação de alimentos retarda a ação de agentes deteriorantes como microorganismos e enzimas, como também diminui as reações químicas. Porém, a qualidade da matéria-prima é 
de fundamental importância para a obtenção de um produto de alta qualidade (Carneiro, 1999).

Processos de conservação através de refrigeração e congelamento, bem como processamentos térmicos, podem alterar fisicamente as carnes podendo promover alterações nos vários componentes. O processo de refrigeração utiliza temperaturas entre $-1^{\circ} \mathrm{C}$ e $10^{\circ} \mathrm{C}$. Este processo não possui ação esterilizante, apenas retarda as atividades microbianas já existentes e impede o surgimento de novos agentes deteriorantes. A refrigeração possibilita a manutenção da qualidade nutritiva da carne, bem como promove a manutenção dos caracteres sensoriais. O congelamento, por empregar temperaturas mais baixas que a refrigeração, prolonga o tempo de conservação da carne. As temperaturas utilizadas diminuem ou paralisam a deterioração causada por microrganismos, enzimas ou agentes químicos. Além disso, o congelamento é um dos melhores métodos para manter a cor, o aroma e a aparência do alimento (Ben, 1999).

No geral, o valor nutritivo dos alimentos submetidos ao congelamento fica integralmente conservado, inclusive, em termos comparativos com os outros métodos de conservação, o congelamento é o que mais preserva a integridade dos nutrientes. Os nutrientes mais sensíveis ao armazenamento congelado, presentes no pescado são a tiamina e o ácido fólico (Instituto del Frio, 1990; Oetterer, 2002).

O congelamento consiste em reduzir a temperatura do alimento (geralmente $\mathrm{a}-18^{\circ} \mathrm{C}$ ), com a conseqüente cristalização de uma parte da água e alguns solutos. Durante o processo de congelamento, a água da solução é transferida para os cristais de gelo, o que resulta na concentração de quase todos os constituintes não aquosos em uma quantidade muito pequena de água não congelada (Robertson, 1992).

Durante a refrigeração, onde são utilizadas temperaturas superiores ao ponto de congelamento do produto, pode-se conservar o produto por um período de 8 a 15 dias, dependendo do tipo de produto. Com o congelamento, 
onde se utilizam temperaturas inferiores ao ponto de solidificação de grande parte da água contida, a conservação do produto $\mathrm{a}-18^{\circ} \mathrm{C}$ é de alguns meses e $\mathrm{a}-30^{\circ} \mathrm{C}$, de um ano (Geromel \& Forster, 1982.)

A velocidade do processo de congelamento é um fator importante para a qualidade final do produto. No congelamento lento há remoção de água das células e grandes cristais de gelo são formados, podendo ocorrer danos físicos aos tecidos e paredes celulares. Desse modo, durante o processo de congelamento, a estrutura dos tecidos pode ser rompida, provocando exsudação e perda de líquidos ocasionando reações indesejáveis que resultam no desenvolvimento de aroma e sabores indesejáveis, redução do valor nutricional e, principalmente, alterações na textura e aparência dos alimentos após o descongelamento. No congelamento rápido os cristais de gelo formados são menores e a qualidade final do produto tende a ser superior (Halász et al., 1982).

A formação de gelo durante o congelamento tem aspecto benéfico e prejudiciais. Os benefícios incluem o fortalecimento das estruturas e a remoção da água livre, com redução da Aa de 0,99 para 0,60 (Van Laack, 1994), em função unicamente da temperatura, independendo da natureza e composição do alimento. Os efeitos prejudiciais incluem as conseqüências da formação de cristais de gelo, como rompimento das estruturas celulares por perfurações, a desidratação parcial do tecido em contato com o cristal de gelo e a concentração dos reagentes (Robertson, 1992).

O congelamento permite a conservação dos alimentos por um longo período, inclusive aqueles com alta atividade de água. $O$ tempo de congelamento $\mathrm{a}-35^{\circ} \mathrm{C}$ por $5 \mathrm{~h}$, caracteriza o congelamento rápido e ideal para manter a textura e a qualidade, pois se congelado lentamente $a-18^{\circ} \mathrm{C}$, parte da água se manterá líquida diminuindo o tempo de vida útil para 6 meses. Uma vez congelados, os produtos devem ser mantidos a uma temperatura de $-18^{\circ} \mathrm{C}$ a $-20^{\circ} \mathrm{C}$ aproximadamente, até o momento de sua utilização pelo consumidor, ou seja, não deve ocorrer nenhuma quebra na cadeia de frio durante o transporte e 
armazenamento nos pontos de venda e na residência do consumidor. A vida útil destes produtos é de mais de 12 meses, se mantidos nas câmaras a $-35^{\circ} \mathrm{C}$. Pela legislação, podem ser comercializados a $-15^{\circ} \mathrm{C}$ nos estabelecimentos de venda ao consumidor (Furtado, 2000).

\subsubsection{Métodos de congelamento}

As empresas brasileiras que trabalham com produtos congelados de pescado marinho, colocam no mercado o produto geralmente congelado a $-35^{\circ} \mathrm{C}$, submetido ao congelador de placas ou túnel de ar frio, muitas das vezes em IQF- “Individually Quick Frozen” (embalagens congeladas individualmente) e em embalagens de caixas de papelão parafinado ou sacos plásticos. Predominam os camarões e os peixes como a merluza (Merluccius merlucius) e a pescada (Cynoscion sp), sendo que as lagostas congeladas, também de excelente qualidade são destinadas à exportação, assim como os camarões (Oetterer, 2002).

O congelamento em salmoura é muito usado para pequenos peixes como a sardinha (Sardinella brasiliensis). Já, o congelamento por ar frio, utilizando túnel de congelamento, é empregado para filés de pescado préembalados e também peixes de grande porte não embalados. O congelamento por contato só pode ser utilizado para produtos de tamanho uniforme, sendo que os congeladores de placas permitem congelar produtos para comercialização direta, filés empanados e polpa de pescado, obtida de descarte do processamento (Bertullo, 1976; Geromel \& Forster, 1982; Halász et al. 1982).

O congelamento por ar circulante (convecção) congela $8 \mathrm{t}$ de peixes em $4 \mathrm{~h}$; os peixes têm que estar acomodados em bandejas especiais, de alumínio ou aço inox, cujos lados são abertos e os intervalos entre prateleiras são suficientes para passagem do ar frio. A escolha do condensador é feita 
conforme as condições climáticas da região e o suprimento e custo da água (Grahn, s.d.).

Os congeladores mais utilizados são os com passagem de ar frio a $-18^{\circ} \mathrm{C}$ a $-40^{\circ} \mathrm{C}$, onde os peixes são acomodados em bandejas e percorrem lentamente um túnel de ar frio; o ar passa em contra corrente com o produto e o congelador de placas, onde o pescado é mantido em contato com uma superfície de metal resfriada por líquido refrigerante como a amônia. A estocagem a $-18^{\circ} \mathrm{C}$, mantém a qualidade do produto por 6 a 8 meses, se o pescado for gordo ou pré cozido; por 10 a 12 meses, para peixes magros e in natura (Fennema, 1975).

Os congeladores criogênicos propiciam as mais baixas temperaturas ao produto, chegando, no caso de pescado a $-45^{\circ} \mathrm{C}$ em 1 minuto. Apesar dos custos do nitrogênio líquido, este procedimento acaba sendo econômico para estocagem longa de produtos de menor volume. Embora o nitrogênio líquido permita o congelamento do alimento a $-196^{\circ} \mathrm{C}$, esta temperatura nunca é praticada devido ao custo e aos danos que provoca no alimento (Instituto del Frio, 1990).

Segundo Beirão et al. (2000), não há dificuldades em se congelar mexilhões com casca por um período mais longo, porém tal procedimento torna-se antieconômico pelo substancial volume ocupado. A carne, depois de cozida e limpa, pode ser embalada em diferentes tipos de embalagens, sendo as mais utilizadas as caixas de papelão e os sacos plásticos, ou até mesmo bandejas específicas para esta finalidade, envoltas em filme retrátil que permite a evacuação do ar, o que aumenta o tempo de conservação do produto. $O$ produto também pode ser submetido diretamente ao processo de congelamento, sem embalagem individual, para só subseqüentemente ser embalado ou receber o glazeamento. O mexilhão deverá ser congelado a uma temperatura máxima de $-27^{\circ} \mathrm{C}$, por um período de 50 minutos e estocado à temperatura de $-18^{\circ} \mathrm{C}$. 


\subsubsection{Velocidade de congelamento}

A velocidade de congelamento é importante, pois define o tamanho dos cristais de gelo e posterior exsudação. No congelamento lento ocorre a formação de cristais de gelo localizados nos espaços extracelulares dos tecidos de tal tamanho que poderão aumentar a possibilidade de rompimento da célula. Quando isso acontece, alterações irreversíveis ocorrem na estrutura celular. Durante o descongelamento, tem-se uma matéria desorganizada incapaz de reabsorver a água perdida e ocorre, como conseqüência, perda de fluido de exsudação, que pode apresentar uma perda significativa de nutrientes (Geromel \& Forster, 1982; Neves Filho, 1991; Soudan, 1965).

Visando um produto congelado de boa qualidade, é importante que a faixa de temperatura que vai de $-1^{\circ} \mathrm{C}$ a $-5^{\circ} \mathrm{C}$ seja ultrapassada $\mathrm{o}$ mais rapidamente possível, pois é está faixa de temperatura que vai definir a velocidade de congelamento e não o tempo total de congelamento. De uma maneira geral, quando a faixa de $-1^{\circ} \mathrm{C}$ a $-5^{\circ} \mathrm{C}$ é ultrapassada em menos de 2 horas, a qualidade do produto é superior, e neste caso, o denominamos de congelamento rápido (Neiva, 2003).

A velocidade de congelamento pode ser medida $\mathrm{em} \mathrm{cm} / \mathrm{h}$ e depende dos seguintes fatores: espessura e composição química do produto, forma em que o produto tem contato com o meio refrigerante e diferença de temperatura entre o produto e o meio refrigerante (Contreras-Guzman, 1982).

O congelamento a $-5^{\circ} \mathrm{C}$, permite que 70 a $75 \%$ da água do pescado congele. A água restante será congelada a temperaturas mais baixas que $-5^{\circ} \mathrm{C}$. Assim, mesmo a $-40^{\circ} \mathrm{C}$ ainda resta $9 \%$ da água em estado líquido. O produto a $-5^{\circ} \mathrm{C}$ pode ser considerado congelado, mas é ainda necessário reduzir a sua temperatura até um valor próximo da temperatura da câmara de estocagem, que trabalha com temperaturas entre $-18^{\circ} \mathrm{C}$ e $-30^{\circ} \mathrm{C}$ (Contreras-Guzman,1982). 
A velocidade de congelamento varia com o método adotado, com o coeficiente de transferência térmica superficial e com a embalagem. Assim, em câmara de circulação de ar forçado, a velocidade é de $1 \mathrm{~mm} / \mathrm{h}$, em congelador de túnel, 3 a $15 \mathrm{~mm} / \mathrm{h}$, em congelador de placas, 12 a $25 \mathrm{~mm} / \mathrm{h}$, em ar forçado contínuo, 15 a $30 \mathrm{~mm} / \mathrm{h}$ e em congelamento por gases liquefeitos, 30 a $100 \mathrm{~mm} / \mathrm{h}$ (Instituto do Frio, 1990). A embalagem de sacos de polietileno com $0,015 \mathrm{~mm}$ de espessura permite o congelamento a $-25^{\circ} \mathrm{C}$ em $3 \mathrm{~h}$ e $30 \mathrm{~min}$; as de cartão parafinado com $1 \mathrm{~mm}$ de espessura, chegam a $-20^{\circ} \mathrm{C}$ em $5 \mathrm{~h}$ e $30 \mathrm{~min}$ (McDonald, s.d.).

No congelamento rápido, cristais muito pequenos são formados dentro e fora da estrutura celular e poucas mudanças são observadas. A desnaturação é limitada e ao retornar à temperatura ambiente, o tecido muscular se encontra em um estado próximo ao seu estado original. Flutuações da temperatura de estocagem favorecem o crescimento dos cristais de gelo e aceleração de reações que reduzem a qualidade do produto, além de provocar maior liberação de líquidos (Neves Filho, 1991).

Dentre as desvantagens do congelamento lento estão a produção de grandes cristais de gelo nas células do pescado podendo romper as paredes celulares; o aumento da concentração de sais e compostos químicos durante o congelamento que pode acelerar a autólise; a temperaturas próximas de $0^{\circ} \mathrm{C}$ alguns tipos de bactérias podem se desenvolver e deteriorar o produto. No produto congelado lentamente há uma maior perda de fluido, ou seja, uma maior exsudação durante o descongelamento (Carneiro, 1999).

\subsubsection{Congelamento e microrganismos}

O congelamento é uma operação importante na conservação de alimentos que visa em primeiro lugar evitar a deterioração e também inibir o desenvolvimento de microrganismos patogênicos responsáveis por problemas de saúde pública. O congelamento dos microrganismos ocasiona injúria celular 
como resultado de diversos processos, dentre eles a formação de cristais de gelo. Portanto, pode ser esperada a inativação de uma parte da população bacteriana especialmente daquela mais sensível ao frio. Quando a temperatura das células bacterianas diminui, a velocidade de todas as reações físicoquímicas que nelas ocorrem também diminui, visto que são processos que dependem da temperatura. Apenas a dissociação e a combinação de radicais livres não obedecem esta regra. Assim, a diminuição da temperatura altera o balanço e modifica a função celular, resultando em lesão bacteriana (El-Kest, 1992).

O hábito de consumir moluscos inteiros incluindo seu trato intestinal, aumenta o risco de surtos de doenças alimentares, pois muitas vezes são ingeridos crus ou parcialmente cozidos ou manipulados em condições higiênicas inadequadas (Claverie, 1986; ICMSF, 1988).

O congelamento não destrói completamente a microflora do produto, mas o número de células viáveis é reduzido durante o processamento e armazenagem. Imediatamente após o congelamento, a eficiência da eliminação de microrganismos varia de acordo com a espécie, sendo que as células que continuam viáveis logo após o congelamento vão, gradualmente, tornando-se inviáveis durante o armazenamento (Sarantopoulos et al., 2001).

No congelamento, a atividade microbiológica é controlada pela limitação da atividade de água e pela temperatura do produto, a qual é muito baixa para permitir a multiplicação, persistindo, porém a possibilidade de sobrevivência de microrganismos patogênicos, além daqueles denominados deteriorantes (Takano et al.,1979).

O declínio no número de microrganismos viáveis é relativamente rápido a temperaturas abaixo do congelamento (principalmente em torno de $-2^{\circ} \mathrm{C}$ ), mas é menor a temperatura inferiores, sendo bastante lento a temperaturas inferiores a $-20^{\circ} \mathrm{C}$ (Sarantopoulos et al., 2001).

A sobrevivência dos microrganismos em um substrato a baixas temperaturas envolve não apenas a sua insensibilidade a estas, mas também a 
sua habilidade na utilização dos nutrientes do ambiente em que se acham, no qual há um constante aumento na concentração dos solutos. A água se torna então cada vez menos disponível, não somente pelo fato de estar sendo congelada, separando-se da solução, mas também em virtude de sua mobilidade reduzida e da sublimação da umidade remanescente. Estas condições levam os microrganismos a um estado de debilidade (Ayres, 1961).

A microflora dos alimentos congelados está constituída por microrganismos mais resistentes do que os que compunham a sua flora inicial. Os esporos mostram alta resistência ao congelamento e, provavelmente, sobrevivam sem mudanças significativas em suas contagens iniciais (Olson \& Nottingham, 1988).

A complexidade dos efeitos do congelamento sobre as células vivas como as dos microrganismos, bem como sobre os alimentos, podem ser assim resumidos: sob congelamento, a água livre forma cristais de gelo desidratando a célula, o que resulta em um aumento da viscosidade do material celular como conseqüência direta da concentração da água na forma de gelo. O processo ocasiona uma perda de gases citoplasmáticos, como oxigênio e gás carbônico, sendo que a perda de oxigênio suprime a reação de respiração das células aeróbicas. Tem-se verificado que o congelamento causa mudanças no $\mathrm{pH}$ do material celular de 0,3 a 2,0 unidades de $\mathrm{pH}$, além de afetar a concentração de eletrólitos celulares, como um efeito da formação de gelo (Jay, 1986).

A temperaturas próximas de $-3^{\circ} \mathrm{C}$ cessa a multiplicação de algumas bactérias e leveduras. Os microorganismos que poderiam deteriorar o pescado não se desenvolvem abaixo de $-10^{\circ} \mathrm{C}$. $\mathrm{A}-12^{\circ} \mathrm{C}$ o crescimento da maioria dos microrganismos é bloqueada. A $-20^{\circ} \mathrm{C}$ cerca de $90 \%$ da água de constituição do pescado encontra-se congelada (Clucas, 1981; Geromel \& Forster, 1982;).

O congelamento é um meio para prolongar a vida útil de carnes e derivados, pois a medida que a temperatura é reduzida, as reações físicas, químicas e bioquímicas que acarretam alterações sensoriais nestes produtos 
passam a ocorrer em baixa velocidade, apesar de não serem completamente paralisadas mesmo quando o alimento é armazenado a $-30^{\circ} \mathrm{C}$. Ao mesmo tempo, parte dos microrganismos deterioradores deixa de se multiplicar, sendo que a maioria das bactérias e fungos parar de se desenvolver $\mathrm{a}-8^{\circ} \mathrm{C}$, e parte é destruída (Paine \& Paine, 1983).

\subsubsection{Armazenamento sob congelamento}

É de fundamental importância a determinação do tempo durante o qual o produto congelado poderá permanecer estocado, mantendo-se em boas condições para o consumo (Carneiro, 1999)

De acordo com Carneiro (1999) a qualidade organoléptica do pescado armazenado congelado como cor, textura, sabor e aroma, diminui em função do tempo de armazenagem. Mudanças de textura e exsudação começam a aparecer a partir de 2 meses de estocagem a $-20^{\circ} \mathrm{C}$.

Segundo o Instituto del Frio (1990), para o pescado é difícil estabelecer um padrão para tempo de congelamento, porém como regra geral, os peixes magros e de músculo branco mantém-se mais tempo com a qualidade máxima na câmara, por 2 anos a $-30^{\circ} \mathrm{C}$. Para ostras e mariscos mantidas a $-18^{\circ} \mathrm{C}$ sua vida útil é de 4 meses, a $-25^{\circ} \mathrm{C}$ é de 10 meses e $\mathrm{a}-30^{\circ} \mathrm{C}$ de 12 meses.

Dentre os principais fatores que causam alterações do produto durante a estocagem tem-se a temperatura, tempo de armazenagem, umidade relativa e circulação em volta do produto e sua embalagem (Neves Filho,1991).

Durante a estocagem, as oscilações de temperatura ocasionam a perda de qualidade do pescado congelado, diminuindo sua vida útil, pois provocam alterações físicas, químicas e biológicas. Os problemas causados pela flutuação da temperatura são maiores em câmaras que trabalham ao redor de $-18^{\circ} \mathrm{C}$. Havendo flutuações de 3 a $4^{\circ} \mathrm{C}$ a essa temperatura, parte dos cristais de gelo vão se liquefazer e congelar. A temperaturas mais baixas, $-25^{\circ} \mathrm{C},-30^{\circ} \mathrm{C}$, 
essa flutuação afetará muito menos o produto, pois praticamente não haverá descongelamento (Sacconi, 1988).

De modo geral, os produtos cárneos congelados possuem, como parâmetro de qualidade, o grau de desnaturação protéica que ocorre durante o armazenamento. A desnaturação de proteínas ocorre devido as condições do congelamento e descongelamento e oscilações de temperatura de armazenamento. Com a desnaturação, as proteínas perdem a capacidade de reter água, o que irá alterar a textura da carne após o descongelamento e suas propriedades funcionais (Ardito, 1994).

Além da desnaturação de proteínas, podem ocorrer no produtos cárneos congelados, desidratação da superfície, oxidação de gordura e alterações na cor (Sarantopoulos et al., 2001).

A desidratação superficial ou queima pelo frio (freezer burn) ocorre quando o produto perde umidade para o ambiente de estocagem através da embalagem. Bolsões de ar que se formam entre a embalagem e o produto também resultam em queima pelo frio, além de dificultar o próprio congelamento atuando como isolante. Contudo, os principais fatores responsáveis pela queima pelo frio são as flutuações de temperatura durante a estocagem e as diferentes etapas de distribuição do produto. O resultado é a formação de cristais de gelo na superfície dos produtos embalados em materiais impermeáveis ao vapor d’água, na medida em que há o descongelamento parcial ou total do produto durante estas flutuações da temperatura. A queima pelo frio prejudica o aspecto da carne, ressecando sua superfície, comprometendo sua coloração, sabor e textura, além de acarretar perda de peso (Karel, 1975).

Estudando mudanças na qualidade de anchovas armazenadas a $-18^{\circ} \mathrm{C}$, Karaçam \& Boran (1996) verificaram que após o período de 3 meses de estocagem o produto ainda é considerado de boa qualidade. Somente após este período as amostras começam a perder o seu frescor. 
Hansen (1980) estudou o efeito da temperatura na qualidade e vida útil de truta (Salmo spp) eviscerada e congelada imediatamente post mortem. $O$ autor verificou que a truta armazenada $\mathrm{a}-10^{\circ} \mathrm{C}$ torna-se rançosa e não tolerável para consumo após 3 a 4 meses de armazenagem; a $-20^{\circ} \mathrm{C}$, após 7 a 8 meses e a $-30^{\circ} \mathrm{C}$, a truta ainda se encontrava em boa qualidade após 9 meses. 


\section{MATERIAL E MÉTODOS}

\subsection{Máteria-prima}

Foram utilizados bivalves da espécie Perna perna provenientes de criatórios da região de Ubatuba, SP.

\subsection{Coleta dos mexilhões}

Foram coletados $40 \mathrm{Kg}$ de mexilhões que foram submetidos ao processo de desdobre, no qual são retirados do cacho, separados da fauna acompanhante, e submetidos à limpeza para a retirada de cracas e parasitas. Posteriormente, os mexilhões foram lavados com água do mar, efetuando-se assim a limpeza da superfície das valvas.

Após este processo, os mexilhões foram acondicionados em embalagens de ráfia e transportados em recipiente isotérmico contendo gelo, na proporção de 3:1 (mexilhão/gelo), sem, no entanto, contato direto com gelo, evitando-se assim a morte dos mexilhões.

\subsection{Processamento dos mexilhões}

O processamento foi realizado no Laboratório de Operações e Processos Unitários do Instituto de Tecnologia de Alimentos-ITAL, localizado em Campinas/SP, conforme o fluxograma apresentado na Figura 1. 


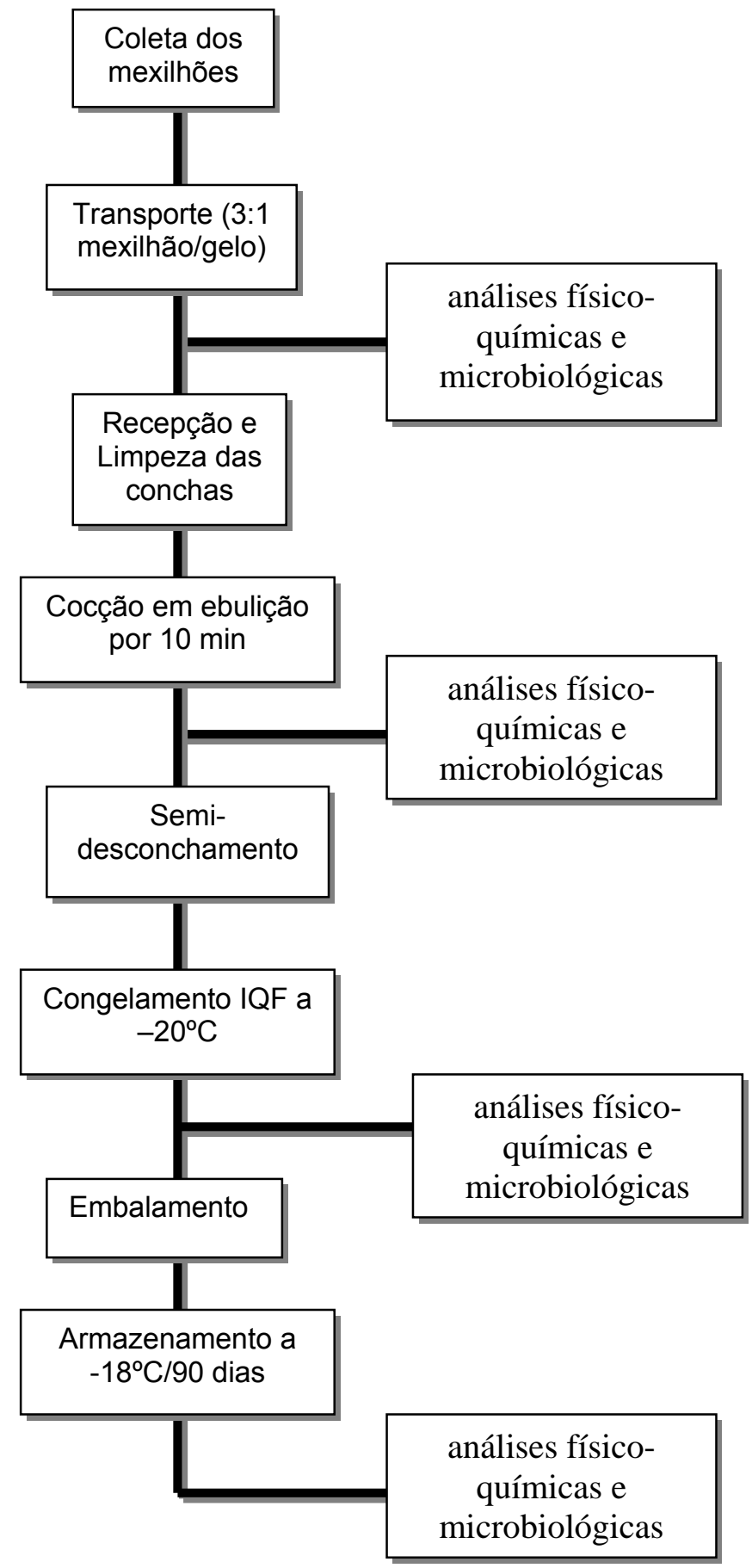

Figura 1 - Fluxograma de processamento e análises do mexilhão 


\subsubsection{Tratamento prévio-cocção}

Primeiramente, os mexilhões foram limpos e higienizados, passando então pelo processo de cocção por imersão em água em ebulição por 10 minutos, monitorados com o auxílio de um conjunto de termopares, até atingirem a temperatura de $96^{\circ} \mathrm{C}$. Após a cocção, os mexilhões foram semidesconchados, fixando os termopares na região central das amostras e colocados em bandejas metálicas perfuradas, sendo então conduzidos para o congelamento.

\subsubsection{Congelamento}

Os mexilhões foram congelados individualmente em IQF, sendo utilizado o método de congelamento por ar circulante com velocidade de $184 \mathrm{~m} / \mathrm{min}$ em câmara de congelamento a $-20^{\circ} \mathrm{C}$ da marca Kitfrigor, com capacidade de $3 \mathrm{~m}^{3}$. As bandejas foram colocadas na parte superior da câmara junto ao circulador de ar, na parte superior perto da porta da câmara e na parte inferior próximo da porta.

A temperatura de congelamento de cada bandeja foi monitorada com auxilio de 3 termopares (medidor de temperatura marca Ellab, modelo TM 9616) com sensores calibrados, sendo 2 fixados na região central das amostras e um solto na bandeja de acordo com a posição na câmara em um total de 10 termopares, designados de T1 a T10, especificamente: T1=solto circulador; T2=superior circulador; T3=superior circulador; T4=solto porta, T5=superior porta, T6=superior porta; T7=solto inferior; T8=inferior circulador; T9=inferior circulador; sendo T10=câmara. As leituras foram realizadas a cada $30 \mathrm{seg}$, com o auxilio do Software E-Vail Basic. Com o término do congelamento as amostras foram embaladas em bandejas de isopor com filme de polietileno, seladas, identificadas e armazenadas em congelador a temperatura de $-18^{\circ} \mathrm{C}$ durante 90 dias. 


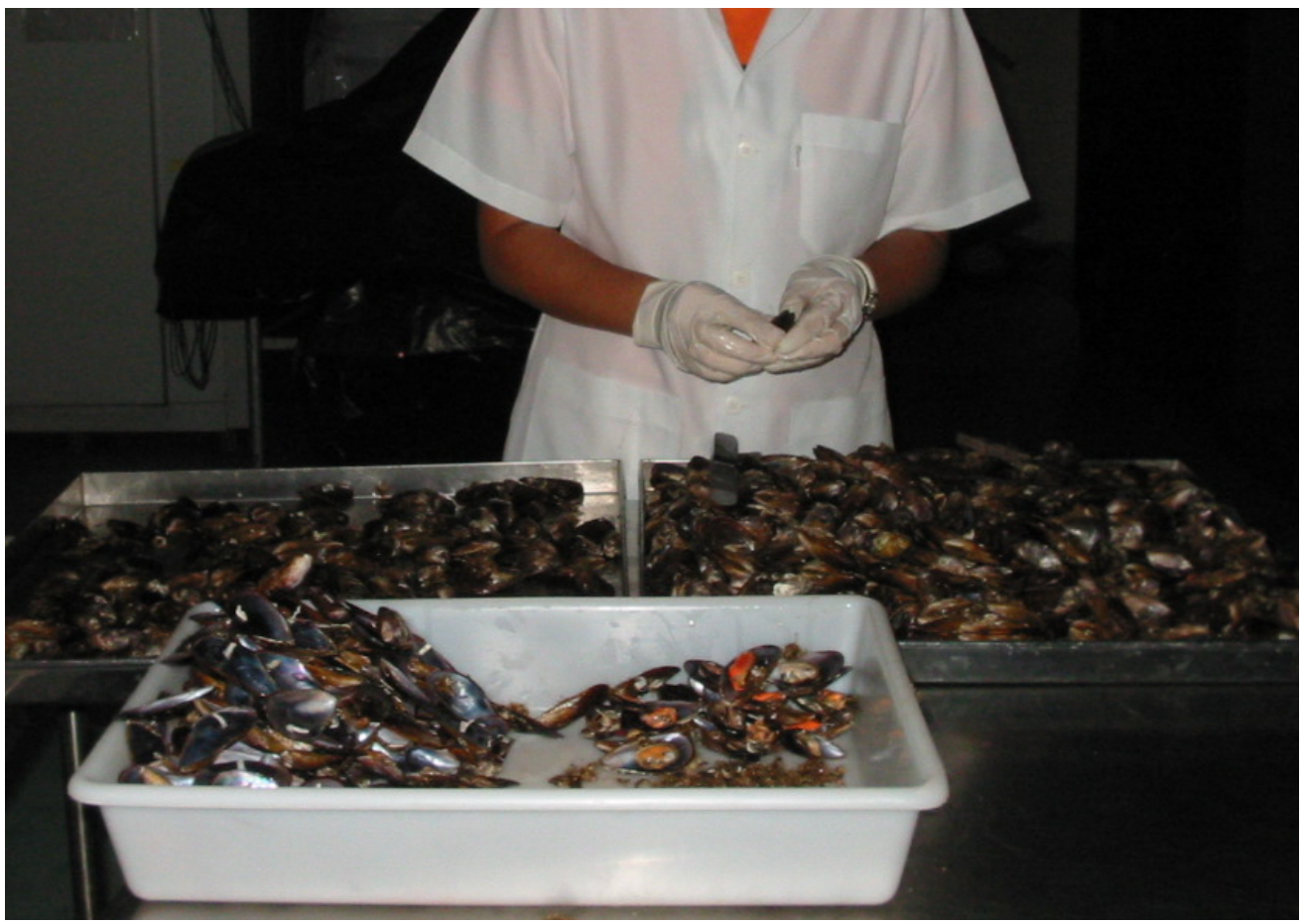

Figura 2 - Desconchamento dos mexilhões.
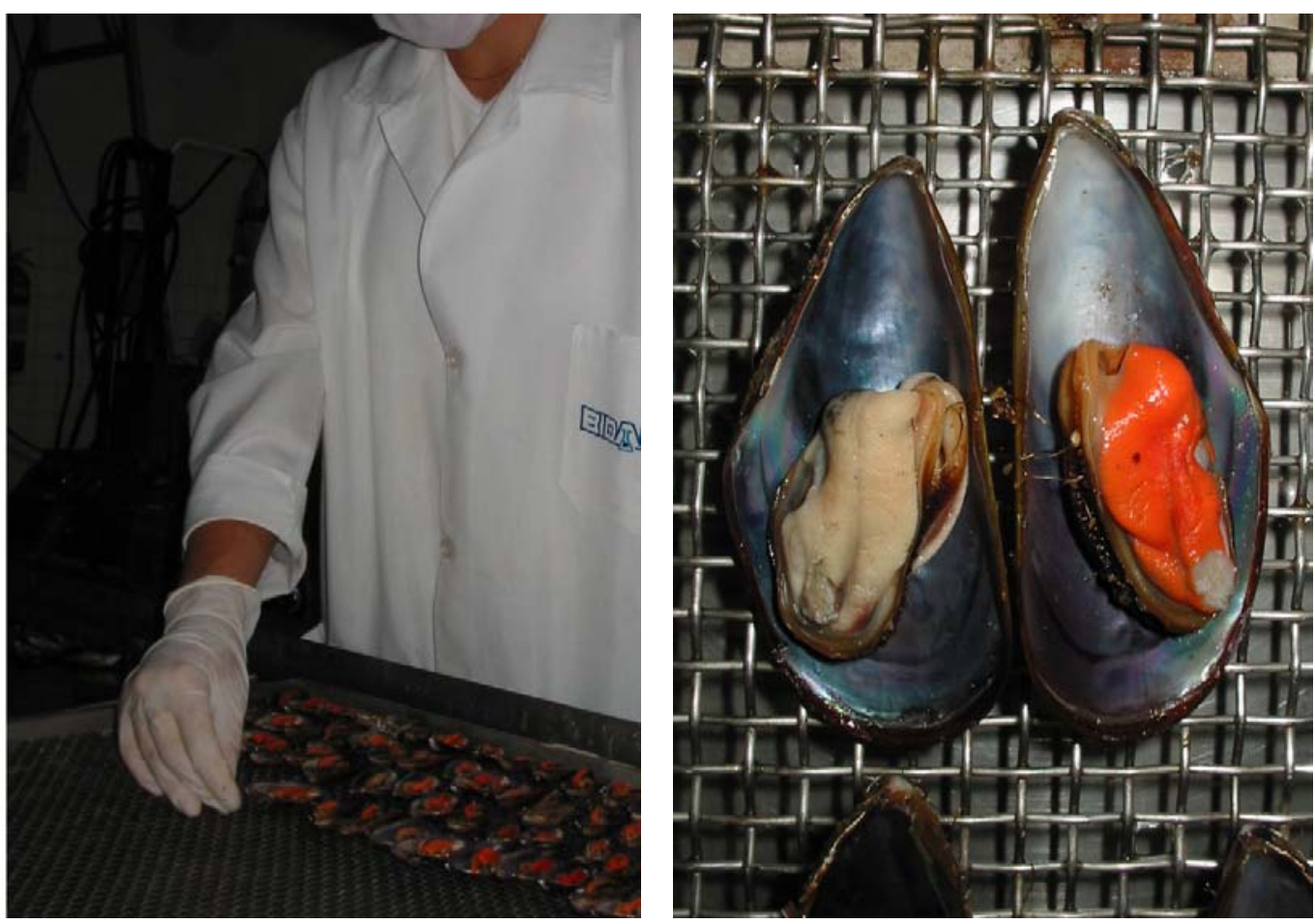

Figura 3 - Distribuição nas bandejas. 


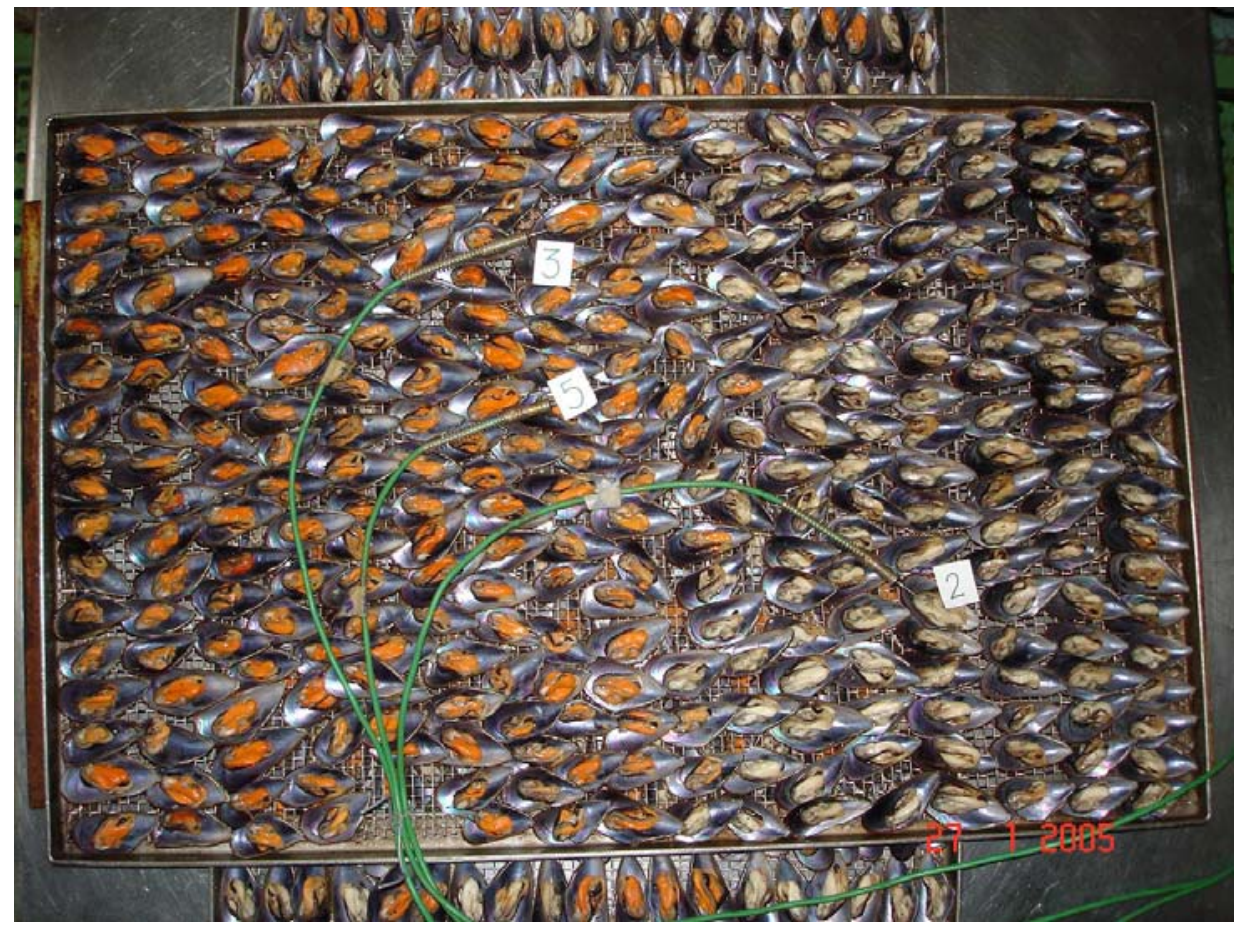

Figura 4 - Bandejas para congelamento em IQF.

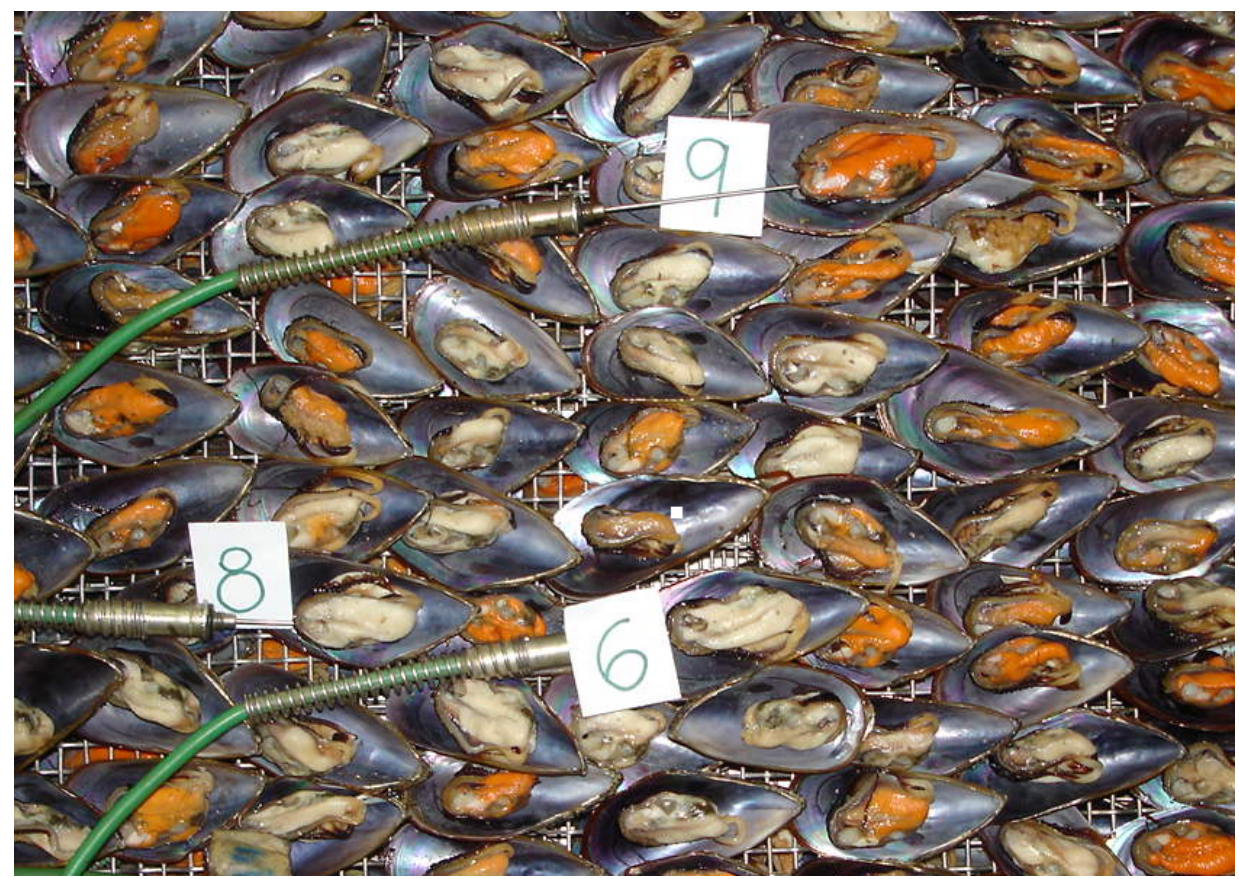

Figura 5 - Distribuição dos termopares nas bandejas. 


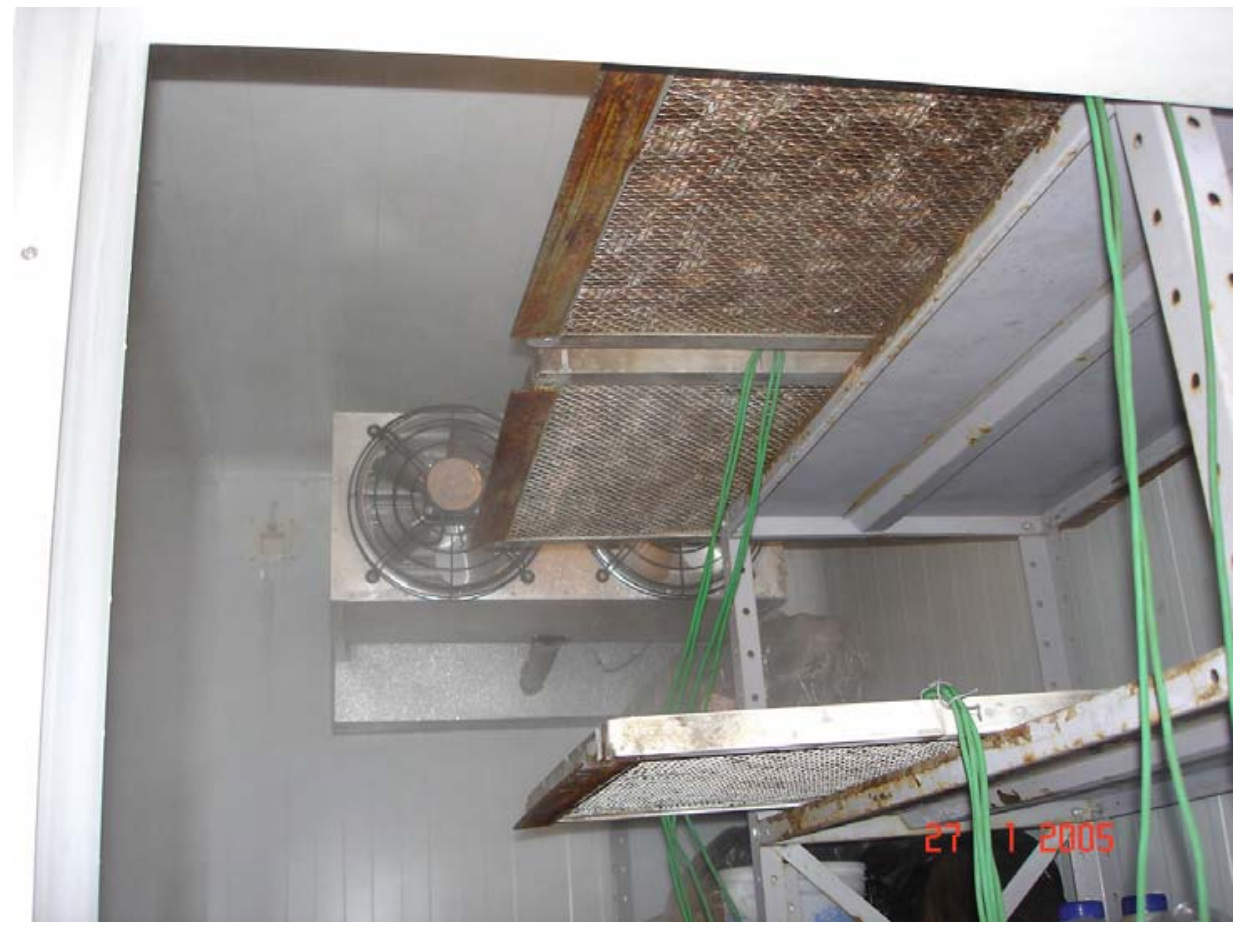

Figura 6 - Câmara de congelamento.

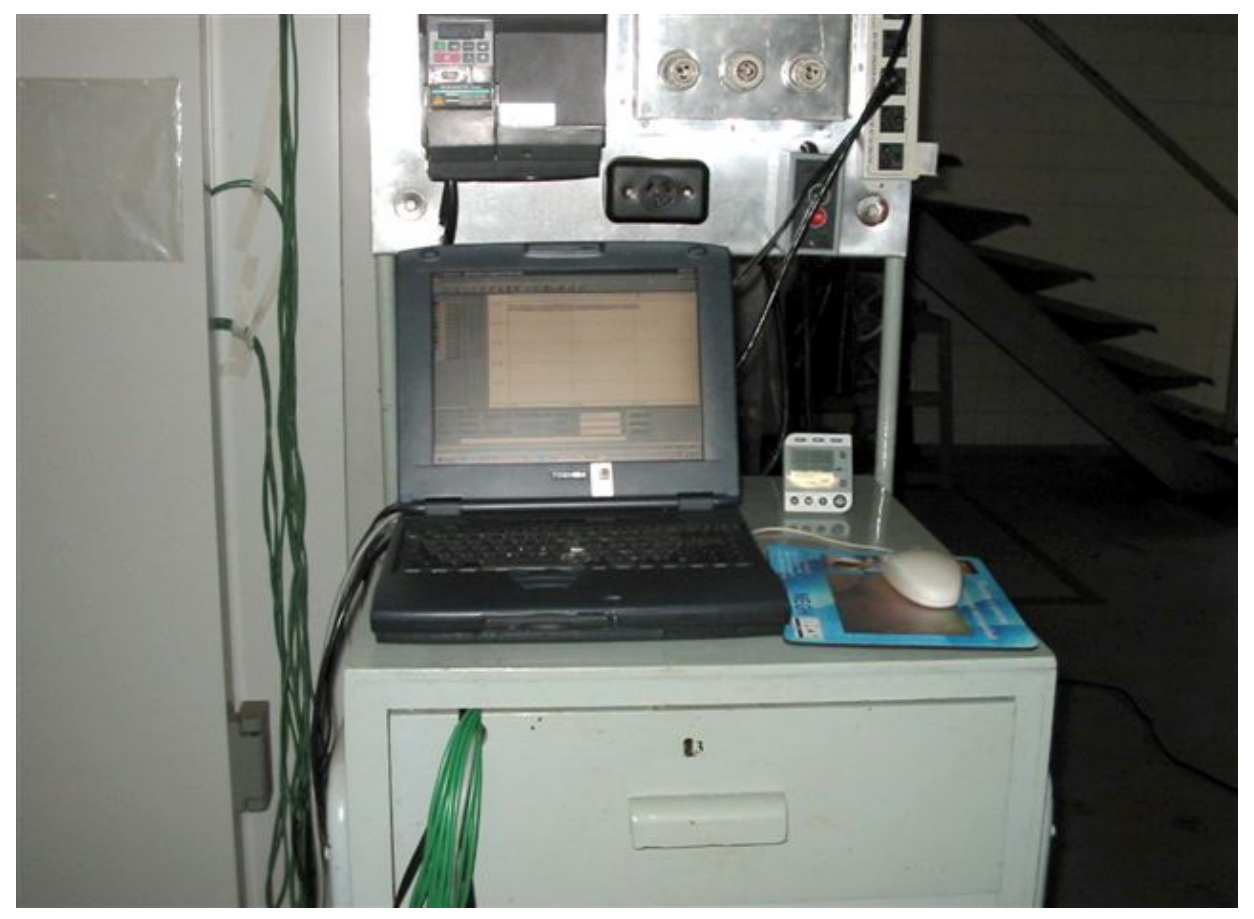

Figura 7 - Software E - Basic. 


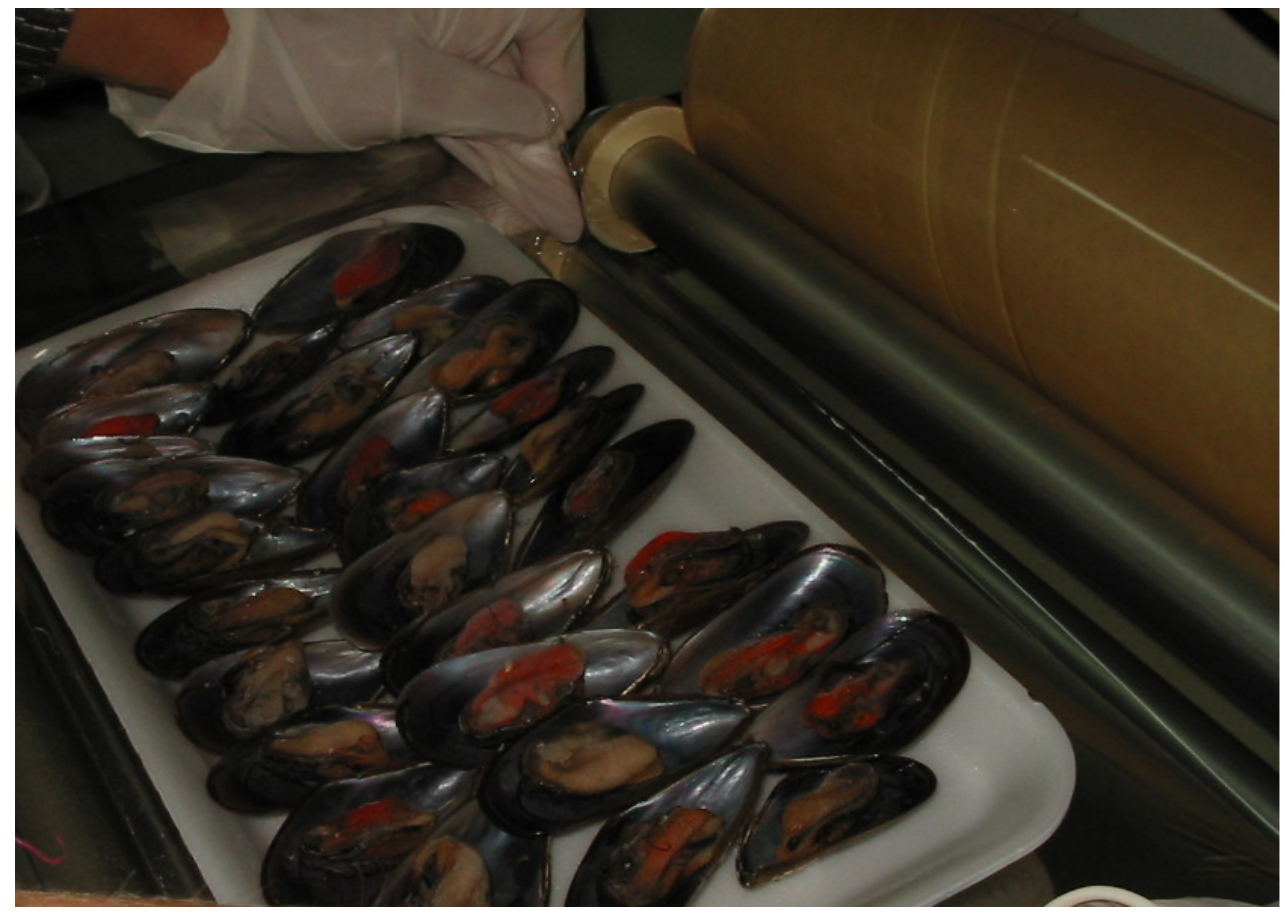

Figura 8 - Embalamento dos mexilhões

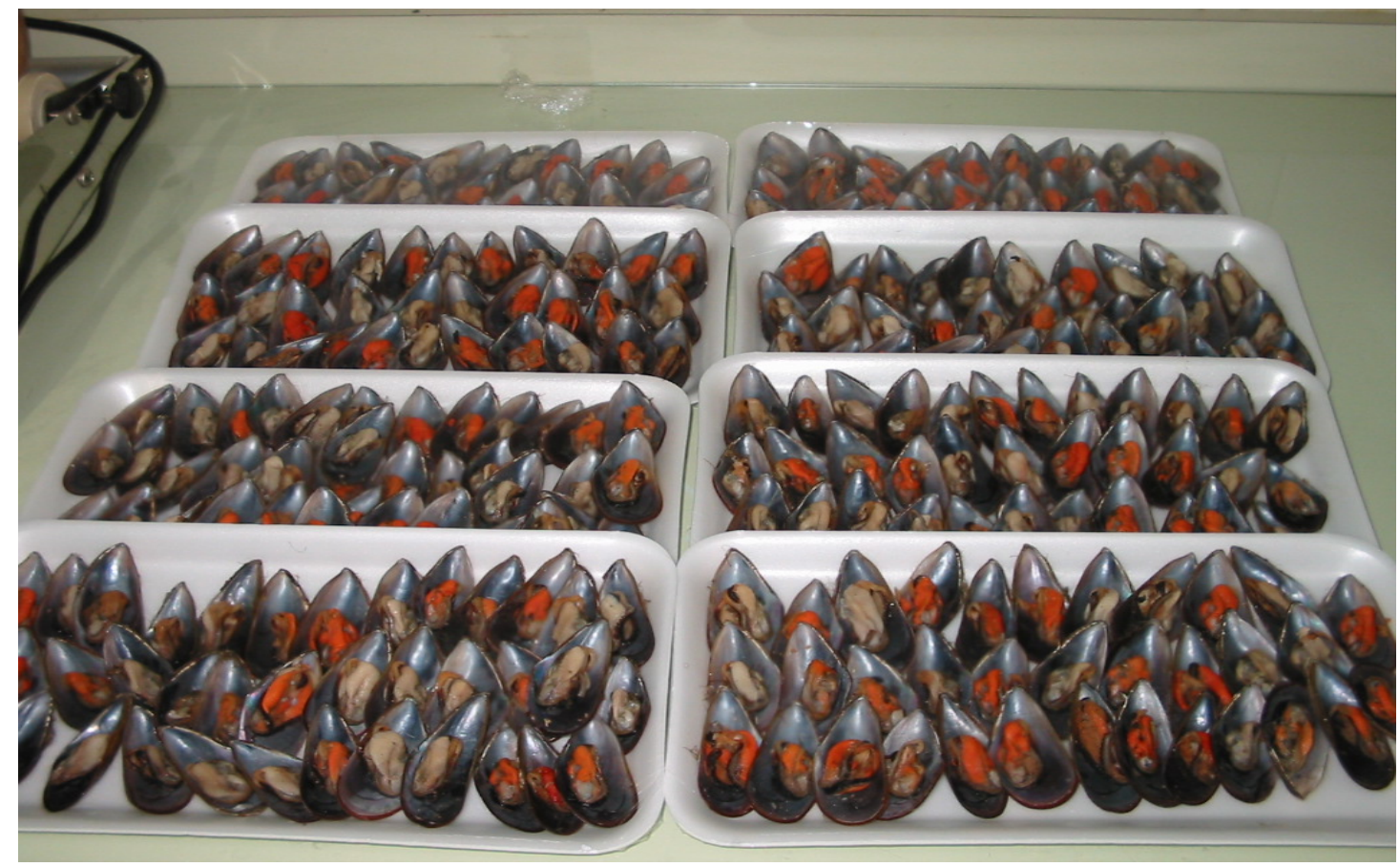

Figura 9 - Mexilhões semi-desconchados congelados 


\subsection{Cálculo da velocidade de congelamento e curva de congelamento}

Os dados foram dispostos em tabelas e procedeu-se ao cálculo da velocidade de congelamento e elaboração da curva de congelamento pela equação de Plank (1963), onde $W=\delta / 2 T$, sendo $\delta=1,2 \mathrm{~cm}$, a espessura do produto e $\mathrm{T}$ o tempo necessário para baixar a temperatura de $0 \mathrm{a}-5^{\circ} \mathrm{C}$.

\subsection{Análises físico-químicas}

As análises de umidade, proteína, lipídeos, cinza e carboidratos foram realizadas segundo A.O.A.C.(1995);

Bases Nitrogenadas Voláteis Totais (BVNT), Trimetilamina (TMA) e determinação de pH, conforme Brasil (1981).

Os valores de Ácido Tiobarbitúrico (TBARS) de acordo com Tarladgis et al. (1960)

O Nitrogênio não protéico pela metodologia descrita por Hungerford (1995).

\subsection{Análises microbiológicas}

As análises foram realizadas no setor de Microbiologia de Alimentos do departamento de Agroindústria Alimentos e Nutrição da Escola Superior de Agricultura "Luiz de Queiroz", ESALQ-USP, em Piracicaba, SP.

\subsubsection{Preparo das diluições}

Foram utilizadas $25 \mathrm{~g}$ de carne, que foram transferidas para um copo de liquidificador estéril; adicionou-se a essa carne $225 \mathrm{~mL}$ de uma solução salina peptonada $0,5 \%$. O material foi homogeneízado em liquidificador a 14.000 rpm, por 60 a 120 seg (Messer et al., 1992). 
Após essa moagem, as diluições decimais de $10^{-2}$ a $10^{-6}$ foram obtidas utilizando-se $1 \mathrm{~mL}$ da diluição anterior e adicionando-se a $9 \mathrm{~mL}$ de uma solução salina peptonada $0,5 \%$.

\subsubsection{Microrganismos analisados nas amostras de mexilhão}

A Contagem de Staphylococcus coagulase+ conforme foi realizada Lancette \& Tataini ( 2001);

Número Mais Provável de coliformes totais e coliformes fecais de acordo com (American Public Health Association-APHA, 1998; Hitchins et al., 2004);

Salmonella descrita por (Andrews et al., 1992; Bennett et al.,1999);

Psicrotróficos e Vibrio parahaemolyticos segundo Silva et al. (1997).

\subsection{Análise estatística}

Os constituintes químicos foram analisados pelo programa estatístico SAS (1999). As médias foram comparadas entre si, pelo teste de Tukey, adotando-se o nível de significância de 5\%. 


\section{RESULTADOS E DISCUSSÃO}

\subsection{Curva de congelamento}

As Figuras 10, 11 e 12 apresentam as curvas de congelamento dos mexilhões de acordo com a localização das bandejas e localização dos termopares na câmara de congelamento.

As curvas de congelamento da presente pesquisa apresentaram uma forma geral típica, sendo compostas de 3 regiões: a de acomodação de temperatura, onde acontece o resfriamento gradual da amostra; o platô que caracteriza a segunda região e corresponde à intensa formação de gelo, que ocorre sobretudo entre zero e $-1,5^{\circ} \mathrm{C}$; na terceira região, percebe-se uma queda brusca de temperatura devido ao aumento da condutividade térmica da amostra já parcialmente congelada e ao menor calor específico. 


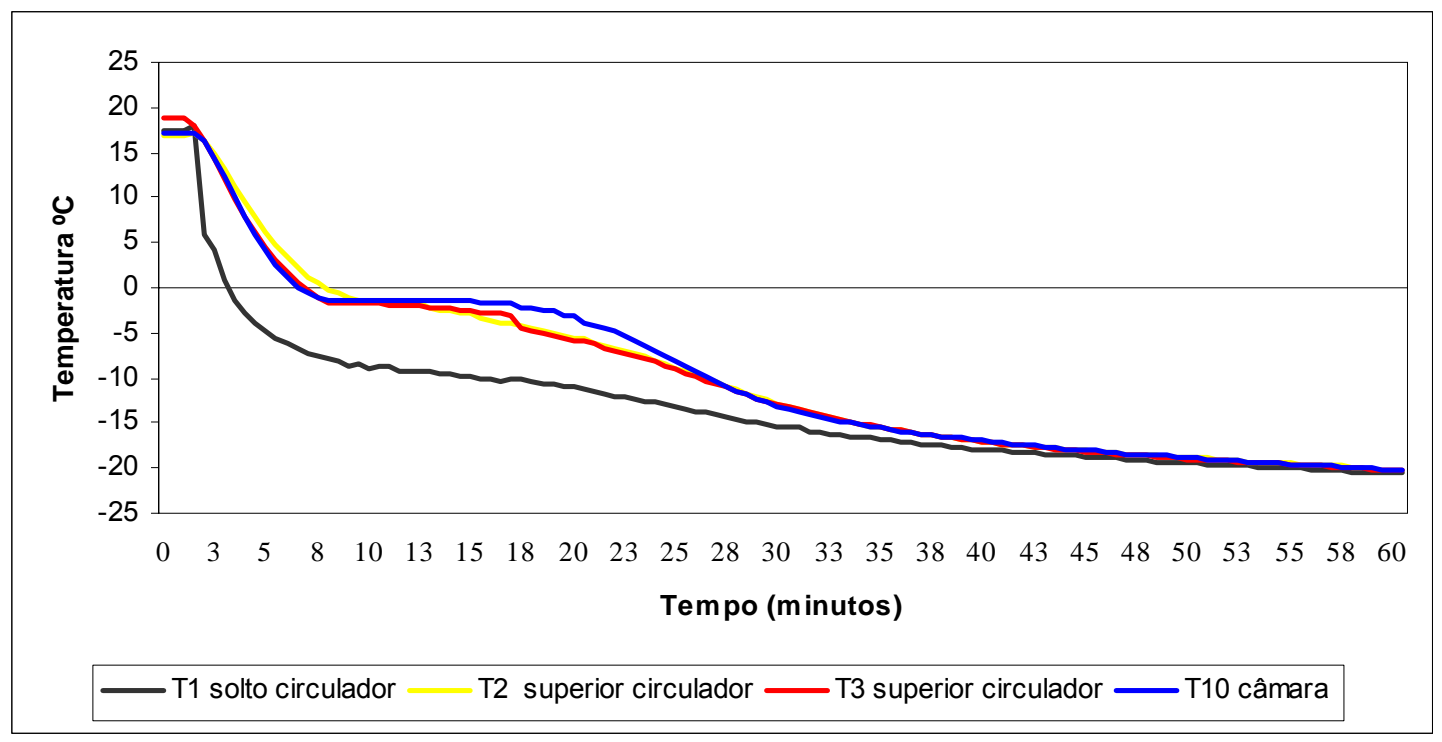

Figura 10 - Curva de congelamento dos mexilhões alojados na parte superior do congelador próximo ao circulador.

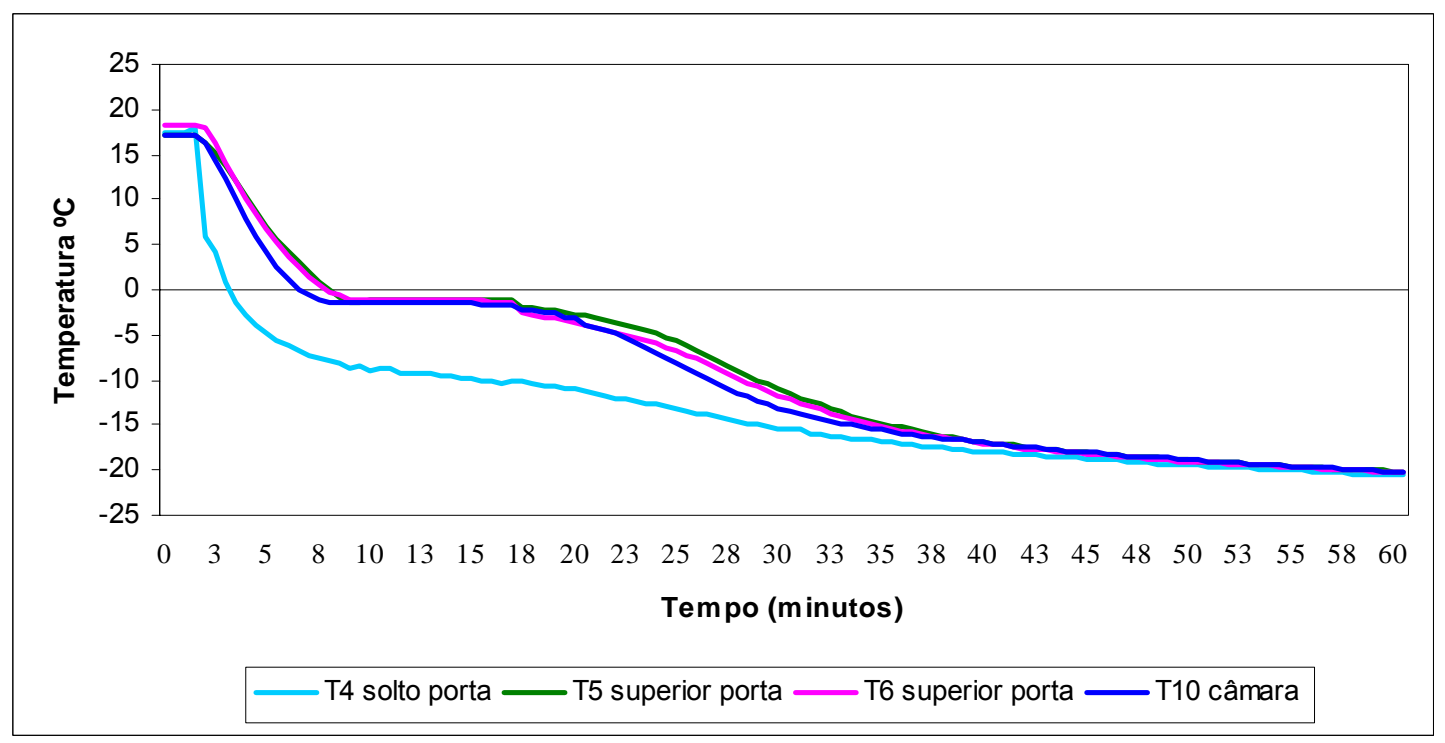

Figura 11 - Curva de congelamento dos mexilhões alojados na parte superior do congelador próximo a porta. 


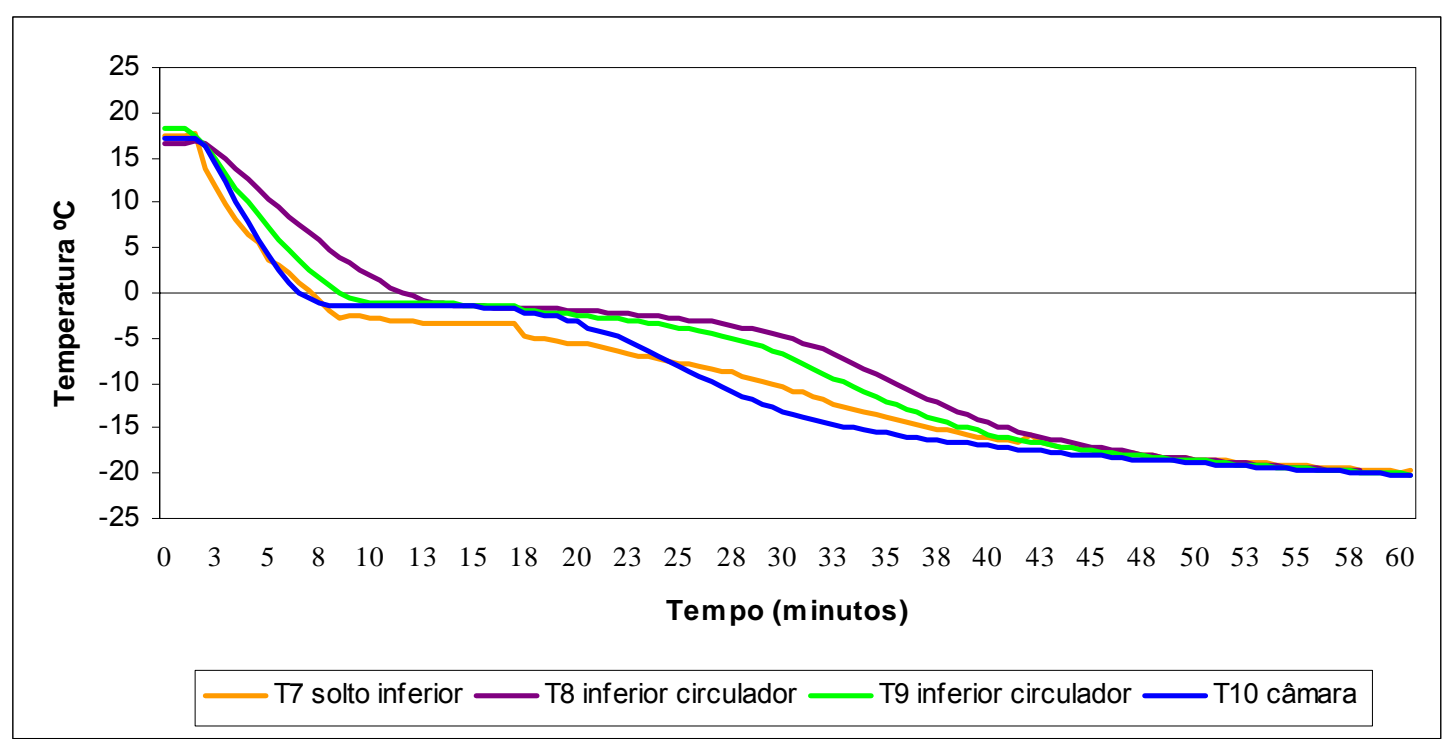

Figura 12 - Curva de congelamento dos mexilhões alojados na parte inferior do congelador próximo ao circulador.

De acordo com Ogawa (1999), a curva de congelamento é elaborada a partir do monitoramento da temperatura medida no centro do alimento. $O$ ponto de congelamento, que varia de espécie para espécie, tecidos, sazonalidade, idade, situa-se geralmente em torno de $-0,5^{\circ} \mathrm{C}$ a $-2,2^{\circ} \mathrm{C}$. $\mathrm{O}$ processo de formação de cristais de gelo se dá no momento em que é liberado calor latente de solidificação de água. Em geral desde o ponto de congelamento até a temperatura de $-5^{\circ} \mathrm{C}$, forma-se um maior número de cristais de gelo, desta forma, esta faixa é denominada de zona de máxima formação de cristais de gelo.

Para peixes de água doce, peixes marinhos (migrantes e demersais) e algas, o ponto de congelamento situa-se em torno de $-0,5,-1,5$ e $-2,0^{\circ} \mathrm{C}$, respectivamente (Ogawa, 1999).

As amostras de mexilhões semi-concha (Figura 10, 11 e 12) atingiram uma faixa de temperatura de $-20^{\circ} \mathrm{C} \mathrm{em}$, aproximadamente, $58 \mathrm{~min}$, com ponto de congelamento na faixa de zero a $-1,5^{\circ} \mathrm{C}$. A porcentagem de 
congelamento atingiu 95\%, o que significa que a água livre foi quase que completamente congelada.

O ponto eutético do alimento, temperatura em que toda a sua água encontra-se congelada, é de aproximadamente $-60^{\circ} \mathrm{C}$. Em torno de $-30^{\circ} \mathrm{C}$, a água livre é quase completamente congelada, mas a água de constituição ainda não entrou no processo de congelamento (Ogawa, 1999).

\subsection{Velocidade de congelamento.}

A Tabela 1 apresenta o tempo e a velocidade de congelamento, conforme monitoramento por termopares inseridos na região central dos mexihões.

Tabela 1. Tempo e velocidade de congelamento dos mexilhões

\begin{tabular}{clcc}
\hline Termopar & Amostras & $\begin{array}{c}\text { Tempo } \\
\left(0 \mathrm{a}-5^{\circ} \mathrm{C}\right) \\
------m i n------\end{array}$ & $\begin{array}{c}\text { Velocidade de } \\
\text { congelamento } \\
------(\mathrm{cm} / \mathrm{h}) \text {-------- }\end{array}$ \\
\hline T2 & superior circulador & 11,0 & 3,3 \\
T3 & superior circulador & 11,3 & 3,2 \\
T5 & superior porta & 16,0 & 2,3 \\
T6 & superior porta & 14,3 & 2,6 \\
T8 & inferior circulador & 18,0 & 2,0 \\
T9 & inferior circulador & 18,3 & 2,0 \\
\hline
\end{tabular}

Os valores obtidos através do cálculo da velocidade de congelamento variaram de $2 \mathrm{~cm} / \mathrm{h}$ a $3,3 \mathrm{~cm} / \mathrm{h}$ para as amostras semidesconchadas, devido à disposição das bandejas dentro da câmara. As bandejas com mexilhão localizadas na parte superior da câmara, próximo ao circulador de ar atingiram a velocidade de congelamento de $3,3 \mathrm{~cm} / \mathrm{h}$, enquanto que a velocidade das bandejas localizadas na parte superior perto da porta foi 
de $2,6 \mathrm{~cm} / \mathrm{h}$ e as localizadas na região inferior do congelador atingiram a $2 \mathrm{~cm} / \mathrm{h}$. Os dados obtidos demonstram claramente que a posição das bandejas na câmara influiu na velocidade de congelamento das amostras.

Para Plank (1963), a caracterização do tipo de congelamento deve seguir o seguinte: $0,1 \mathrm{~cm} / \mathrm{h}$ para congelamento lento; $1-5 \mathrm{~cm} / \mathrm{h}$ para o congelamento de velocidade média e $>5 \mathrm{~cm} / \mathrm{h}$ para congelamento rápido. Portanto, a velocidade de congelamento dos mexilhões IQF em câmara de ar forçado, está dentro da faixa de $1-5 \mathrm{~cm} / \mathrm{h}$, caracterizado como congelamento de velocidade média.

Segundo o Instituto Internacional del Frio (1990), os valores mais comuns encontrados na prática e seus respectivos processos são: $0,2 \mathrm{~cm} / \mathrm{h}$ (lento), para congelamento a granel em câmaras frias ventiladas; 0,5 a $3 \mathrm{~cm} / \mathrm{h}$ (rápido), para produtos embalados e congelados em câmaras de ar forçado ou em congeladores de placas; 5 a $10 \mathrm{~cm} / \mathrm{h}$ (rápido), para congelamento individual de produtos de pequenas dimensões, como no sistema de leito fluidizado; 10 a $100 \mathrm{~cm} / \mathrm{h}$ (ultra-rápido), para congelamento em "spray" e/ou imersão em gases liquefeitos.

\subsection{Análises Físico-Químicas}

A Tabela 2 apresenta a composição química dos mexilhões in natura e processados.

\subsubsection{Composição Centesimal}


Tabela 2. Composição centesimal dos mexilhões in natura, processados e armazenados durante 90dias

\begin{tabular}{lccccc}
\hline Tratamento & Umidade & Proteína & Lipídeos & Cinza & Carboidratos \\
\hline $\begin{array}{l}\text { In natura } \\
\text { Submetidos à }\end{array}$ & $85,8^{\mathrm{a}}$ & $7,2^{\mathrm{a}}$ & $1,2^{\mathrm{a}}$ & $1,9^{\mathrm{a}}$ & $3,8^{\mathrm{a}}$ \\
cocção & $81,0^{\mathrm{a}}$ & $7,5^{\mathrm{a}}$ & $1,5^{\mathrm{a}}$ & $1,9^{\mathrm{a}}$ & $8,1^{\mathrm{a}}$ \\
Congelado & $84,2^{\mathrm{a}}$ & $7,3^{\mathrm{a}}$ & $1,5^{\mathrm{a}}$ & $1,8^{\mathrm{a}}$ & $5,1^{\mathrm{a}}$ \\
Armazenado & $83,0^{\mathrm{a}}$ & $7,5^{\mathrm{a}}$ & $1,6^{\mathrm{a}}$ & $1,8^{\mathrm{a}}$ & $6,2^{\mathrm{a}}$ \\
\hline Desvio Padrão & 2,05 & 0,23 & 0,16 & 0,05 & 1,58 \\
\hline
\end{tabular}

Nota: médias seguidas da mesma letra não diferem entre si ao nível de $5 \%$ de probabilidade.

Porrelli et al. (2003), avaliando a composição centesimal de mexilhões Perna perna coletados mensalmente de outubro/2002 a fevereiro/2003 no cultivo do Costão do Cedro em Ubatuba-SP, encontraram em tais determinações, os seguintes valores: $83,9 \%$ de umidade; $9 \%$ de proteína; $1 \%$ de lipídeos; 1,9 de cinza e $4 \%$ de carboidratos.

Para o mexilhão in natura, obteve-se valores médios de 85,$8 ; 7,2$; 1,$2 ; 1,9 ; 3,8 \mathrm{~g} / 100 \mathrm{~g}$, respectivamente, para umidade, proteína, lipídeos, cinza e carboidratos, estando estes valores próximos aos apresentados na Tabela da Associação Catarinense de Aqüicultura - ACAQ (2004), que para o mesmo marisco estudado nesta pesquisa apresenta valores de $83 ; 12 ; 1,5 ; 1,9$ e $3 \mathrm{~g} / 100 \mathrm{~g}$, respectivamente, para estes componentes.

Salan (2005), para mexilhões in natura da espécie Perna perna, obteve valores médios de 82,82; 11,78; 1,55 e 2,37 g/100g, respectivamente, para umidade, proteína, lipídeos e cinza.

\subsubsection{Umidade}


Os teores médios de umidade encontrados nesta pesquisa para mexilhões in natura, foram semelhantes aos encontrados por Furlan (2004), 81,41 a 85,37 g/100g, Salan (2005), 82,82g/100g e Magalhães (1986), 78,3 a $89,77 \mathrm{~g} / 100 \mathrm{~g}$, para mexilhão in natura. Sendo valores superiores aqueles obtidos por Tavares et al. (1988), da ordem de 72,12 g/100g para a mesma espécie in natura.

Para o mexilhão cozido o valor encontrado de umidade foi de $81 \mathrm{~g} / 100 \mathrm{~g}$ próximo aos valores obtidos por Schramm (1993), entre 75 e $82 \mathrm{~g} / 100 \mathrm{~g}$, em mexilhões pré-cozidos em água fervente por 5 minutos. Já Salan (2005), em mexilhões imersos em água à ebulição por 10 minutos, encontrou valores inferiores, cerca de $77,23 \mathrm{~g} / 100 \mathrm{~g}$.

$\mathrm{Na}$ base de dados de nutrientes do Departamento de Agricultura dos Estados Unidos (USDA), consta que a espécie azul Mytilus edulis L. apresenta $81 \mathrm{~g} / 100 \mathrm{~g}$ de umidade in natura e $61 \mathrm{~g} / 100 \mathrm{~g}$ após cocção (USDA, 2005). Portanto, a variação no teor de umidade pode estar relacionada ao método de preparo ou metodologia de obtenção de amostras.

Observa-se pela Tabela 2 que após cocção ocorreu leve exsudação, diminuindo o teor de umidade; durante o congelamento, provavelmente houve ligeiro acúmulo de água não ligada no produto.

\subsubsection{Proteínas}

Para proteínas, o teor médio encontrado foi de $7,3 \mathrm{~g} / 100 \mathrm{~g}$ não havendo diferença significativa entre o mexilhão in natura, cozido, congelado e armazenado por 90 dias, estando estes valores de acordo com Gelli (1992) que encontrou teores de 6,7 a 9,58g/100g, inferiores aos obtidos por Magalhães (1986) e Furlan (2004), a saber, 9,68 g/100g a 9,09 g/100g e 9,6 a $10,73 \mathrm{~g} / 100 \mathrm{~g}$, respectivamente, para mexilhões in natura.

Salan (2005), encontrou valores de $11,78 \mathrm{~g} / 100 \mathrm{~g}$ para mexilhões in natura e $16,80 \mathrm{~g} / 100 \mathrm{~g}$ para mexilhões cozidos imersos por 10 minutos à 
ebulição, enquanto Tavares et al. (1998), encontraram teores superiores para proteína, da ordem de $20 \mathrm{~g} / 100 \mathrm{~g}$, o que pode ser explicado por diversos fatores como região de coleta, diferentes estádios de reprodução e de metodologias utilizadas (Magalhães, 1986).

Não foi verificada alteração no teor de proteína pelo processo de congelamento e armazenamento, fato que caracteriza os benefícios do congelamento na manutenção da qualidade nutricional deste pescado.

\subsubsection{Lipídeos}

Os lipídeos não sofreram oscilações durante o processamento e armazenamento; a média geral para este componente foi de $1,4 \mathrm{~g} / 100 \mathrm{~g}$, concordando com Furlan (2004), que encontrou para a mesma espécie valores entre 0,99 e 1,49 g/100g. De acordo com Ackman (1999), o conteúdo em lipídeos de mariscos situa-se entre 1 e $2 \mathrm{~g} / 100 \mathrm{~g}$. Os bivalves armazenam suas reservas de energia na forma de glicogênio e não como gordura.

\subsubsection{Cinza}

Não houve oscilações nos teores de cinza para os mexilhões in natura, cozidos e congelados; a média geral para este componente foi de $1,8 \mathrm{~g} / 100 \mathrm{~g}$, estando de acordo com a média geral de $1,79 \mathrm{~g} / 100 \mathrm{~g}$ encontrada por Furlan (2004).

\subsubsection{Carboidratos}

Para os carboidratos, os teores encontrados variaram de $3,8 \mathrm{~g} / 100 \mathrm{~g}$ para mexilhões in natura, $8,1 \mathrm{~g} / 100 \mathrm{~g}$ para o cozido, $5,1 \mathrm{~g} / 100 \mathrm{~g}$ para o congelado, e 6,4 g/100g após armazenamento de 90 dias, apresentando uma relação inversa aos teores de umidade. Os resultados obtidos estão dentro da faixa de 1,86 a 7,22 g/100g para o mexilhão in natura, obtidos por Furlan 
(2004). No entanto estão superiores aos encontrados por Salan (2005), $1,98 \mathrm{~g} / 100 \mathrm{~g}$ para o mexilhão in natura e 1,87 para o mexilhão pré-cozido.

\subsubsection{Padrões de Qualidade}

\subsubsection{BNVT e TMA}

A Tabela 3 apresenta os teores de Bases Nitrogenadas Voláteis Totais e Trimetilamina dos mexilhões.

Tabela 3. BNVT e TMA dos mexilhões in natura, processados e armazenados congelados

\begin{tabular}{|c|c|c|}
\hline \multirow{2}{*}{ Tratamento } & BNVT & TMA \\
\hline & \multicolumn{2}{|c|}{ 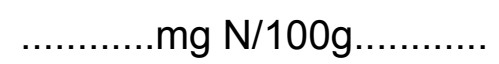 } \\
\hline In natura & $4,3^{\mathrm{a}}$ & $2,0^{a}$ \\
\hline Submetido à cocção & $5,0^{a}$ & $0,6^{a}$ \\
\hline Congelado & $4,0^{a}$ & ND \\
\hline Armazenado congelado & $4,2^{a}$ & $0,2^{\mathrm{a}}$ \\
\hline Desvio padrão & 0,9 & 1,2 \\
\hline
\end{tabular}

Médias seguidas da mesma letra não diferem entre si em nível de 5\% de probabilidade.

Em estudo realizado por Furlan (2004), entre os meses de novembro a março, com mexilhão Perna perna in natura cultivado em Ubatuba, SP encontrou-se valores para BNVT de 5,6mg/100g a $11 \mathrm{mg} / 100 \mathrm{~g}$, e TMA de 0,6 $\mathrm{mg} \mathrm{N} / 100 \mathrm{~g}$ a $7,7 \mathrm{mg} \mathrm{N} / 100 \mathrm{~g}$.

Lakshmanan et al. (1992), estudando peças de pescado congelado, encontraram um incremento nos valores de BNVT durante o tempo de estocagem. $\mathrm{O}$ aumento era maior à medida que se elevava a temperatura de estocagem. 
Tomando-se como base a legislação vigente (Brasil, 1980), o pescado fresco deve apresentar níveis de BNVT inferiores a $30 \mathrm{mg} \mathrm{N} / 100 \mathrm{~g} \mathrm{e}$ TMA $4 \mathrm{mg} \mathrm{N} / 100 \mathrm{~g}$; as legislações do Japão e da Austrália têm como limite 5 mg N/100g (Jay, 1994). Portanto, os valores de BNVT e TMA encontrados nesta pesquisa estão de acordo com as legislações nacional e internacional.

Segundo Regensteim et al. (1982), a habilidade dos microrganismos em elaborar TMA é diminuída pela estocagem em gelo e pelo $\mathrm{pH}$ reduzido, o que limita seu uso como indicador de qualidade. Nesta pesquisa ocorreu ausência de TMA no mexilhão congelado, conforme ilustra a Tabela 3.

\subsubsection{Nitrogênio não protéico}

A tabela 4 apresenta os dados da variação do Nitrogênio não protéico e do $\mathrm{pH}$ dos mexilhões, in natura, processados e armazenados congelados.

Tabela 4. NNP e pH dos mexilhões in natura, processados e armazenados

\begin{tabular}{lcc}
\hline Tratamento & NNP $(\mathrm{mg} \mathrm{N} / 100 \mathrm{~g})$ & $\mathrm{pH}$ \\
\hline In natura & $1.200,93^{\mathrm{a}}$ & $6,2^{\mathrm{b}}$ \\
Submetido à cocção & $706,67^{\mathrm{b}}$ & $6,9^{\mathrm{a}}$ \\
Congelado & $666,7^{\mathrm{b}}$ & $6,9^{\mathrm{a}}$ \\
Armazenado congelado & $486,66^{\mathrm{c}}$ & $6,9^{\mathrm{a}}$ \\
\hline Desvio padrão & 257,1 & 0,3 \\
\hline
\end{tabular}

Médias seguidas da mesma letra não diferem entre si em nível de $5 \%$ de probabilidade.

Os valores de NNP foram afetados significativamente $(p>0,05)$ pelo processamento dos mexilhões. Para os mexilhões in natura, os resultados obtidos para NNP foram de $1.200,93 \mathrm{mg} / 100 \mathrm{~g}$, estando de acordo com os valores encontrados por Furlan (2004) de 680 mg/100 a 2.010 mg/100g, para os mexilhões analisados após 24 horas da coleta, considerando que os animais 
estudados apresentavam-se vivos até o momento da análise, os índices apresentados não correspondem aos compostos nitrogenados não protéicos utilizados pelos microrganismos, visto que o músculo do pescado apresenta-se estéril até o momento da sua morte.

Segundo Skorsksi et al. (1994) o NNP é utilizado para determinação do frescor, por ser a primeira fração a ser utilizada pelos microrganismos, servindo de fonte de energia para os mesmos.

Nota-se na tabela 4 que houve um decréscimo de NNP dos mexilhões in natura para os mexilhões submetidos à cocção, congelados e armazenados. Este fato pode levar a supor que o NNP não deva ser adequado como índice de avaliação na qualidade dos mexilhões in natura, cozidos, congelados e armazenados, pois os microrganismos, com o tratamento térmico e posterior congelamento e armazenamento foram erradicados ou reduzidos.

De acordo com Netto (1984), a tilápia do Nilo (Oreochromis niloticus) apresentou, inicialmente, $294 \mathrm{mg} / 100 \mathrm{~g}$, e após 20 dias de estocagem em gelo, ocorreu uma redução para $208 \mathrm{mg} / 100 \mathrm{~g}$. O autor atribuiu os teores mais altos do NNP, na fase inicial, às atividades das catepsinas e nas fases posteriores, às proteases microbianas.

Amanajás (1985) afirmou que o critério é não recomendar a determinação global do NNP como índice de frescor, mesmo porque não existem padrões estipulados legalmente para este fim.

\subsubsection{3 $\mathrm{pH}$}

Os valores encontrados para o pH estão de acordo com os dados obtidos por Oetterer (2003) e Furlan (2004) para mexilhões in natura, e Salan (2005) para mexilhões processados da espécie, Perna perna coletados em Ubatuba, variando de 5,8 a 6,9; 6,14 a 7,2 e 6,87 a 7,11 respectivamente.

Não houve alteração no valor do pH pelo processamento, mantendose inalterado durante o armazenamento. 
Segundo o R.I.I.S.P.O.A (Regulamento de Inspeção Industrial e Sanitária dos Produtos de Origem Animal), o limite de pH para carne externa de pescado dever ser inferior a 6,8 e para interna, inferior a 6,5, sendo que não há especificação de limites para moluscos (Brasil, 1980).

Os valores de $\mathrm{pH}$ de carne de pescado congelado têm levado a algumas controvérsias. Alguns autores, citados por Mills (1975), afirmaram não ocorrer alteração, durante o armazenamento sob congelamento, enquanto outros defendem que há oscilações. O autor conclui que estas observações conflitantes não devem surpreender, uma vez que podem ocorrer reações que produzem ácidos e bases durante o congelamento.

\subsubsection{4 Ácido tiobarbitúrico (TBA)}

A tabela 5 apresenta os teores das substancias reativas ao ácido tiobarbitúrico nas amostras de mexilhão.

Tabela 5. TBA dos mexilhões in natura, processados e armazenados congelados

Tratamento

TBA

(mg de malonaldeido/kg)

\begin{tabular}{lc}
\hline In natura & $3,03^{\mathrm{ab}}$ \\
Submetido à cocção & $2^{\mathrm{b}}$ \\
Congelado & $2,36^{\mathrm{b}}$ \\
Armazenado congelado & $2,57^{\mathrm{b}}$ \\
\hline Desvio padrão & 0,5 \\
\hline
\end{tabular}

Médias seguidas da mesma letra não diferem entre si em nível de 5\% de probabilidade.

Morris \& Dawson (1979) através de estudos realizados com pescado, indicam que o TBA é um método eficiente para se avaliar o desenvolvimento da oxidação de lipídeos neste tipo de alimento. 
Para Al-Kahtani et al. (1996) o produto pode ser considerado em bom estado, apresentando valores abaixo de $3 \mathrm{mg}$ de malonaldeído/kg de amostra. A legislação vigente no Brasil, não apresenta limite máximo para malonaldeído/kg em produtos cárneos, sendo que, para o parâmetro citado, conforme ilustrado na tabela 5 , todas as amostras apresentaram-se de acordo.

Segundo Schormüller (1974) o produto ser considerado de qualidade perfeita, quando o valor de TBA for menor que $3 \mathrm{mg}$ de malonaldeído/kg., produtos de boa qualidade, menor que $5 \mathrm{mg}$ de malonaldeído/kg e aptos para consumo na faixa de 7 a $8 \mathrm{mg}$ de malonaldeído/kg.

A fração lipídica dos alimentos está relacionada a diversas propriedades organolépticas como aroma, coloração, textura, suculência, estabilidade das proteínas, vida útil sob congelamento e conteúdo calórico (Allen \& Foegeding, 1981).

Manousaridis et al. (2005) encontraram valores de 13 a $23 \mathrm{mg}$ de malonaldeido/kg em estudo realizado com mexilhões in natura da espécie Mytilus galloprovincialis embalados a vácuo, durante 12 dias de armazenamento refrigerado.

Sant' Ana \& Fernandes (2000) avaliaram a oxidação lipídica, através dos teores de TBA, em filés de pacu (Piaractus mesopotamicus) sob armazenamento congelado. Foi observado um gradual aumento da oxidação, estando os valores de TBARS em torno de 0,41;0,62;0,59 e 1,49 mg de malonaldeído/kg de peixe, respectivamente, no inicio e após 30,60 e 90 dias de armazenamento.

\subsection{Análises microbiológicas}

A Tabela 6 apresenta os resultados da análise microbiológica dos mexilhões. 
Tabela 6. Microrganismos em mexilhões in natura, processados e armazenados congelados por 90 dias

\begin{tabular}{|c|c|c|c|c|}
\hline Microrganismos & In natura & $\begin{array}{l}\text { Submetido à } \\
\text { cocção }\end{array}$ & Congelado & Armazenado \\
\hline Coliforme total (NMP/g) & $1,1 \times 10^{2}$ & 0,9 & 0,4 & 0,2 \\
\hline Coliforme fecal (NMP/g) & 9,3 & ausência & ausência & ausência \\
\hline Salmonella sp (em 25g) & ausência & ausência & ausência & ausência \\
\hline $\begin{array}{l}\text { Staphylococcus } \\
\text { coagulase+ (UFC/g ) }\end{array}$ & $7 \times 10^{1}$ & $10^{1}$ & $<1,0$ & $<1,0$ \\
\hline Psicrotróficos (UFC/g) & $9,3 \times 10^{3}$ & $3,1 \times 10^{1}$ & $3,8 \times 10^{2}$ & $7 \times 10^{1}$ \\
\hline $\begin{array}{l}\text { V.parahaemolyticus } \\
\text { (NMP/g) }\end{array}$ & $<1,0$ & $<1,0$ & $<1,0$ & $<1,0$ \\
\hline
\end{tabular}

Em moluscos in natura as contagens totais de microrganismos referem-se ao conteúdo intravalvar carne-líquido, e a população microbiana pode oscilar entre $10^{4}$ e $10^{6}$ UFC/g (ICMSF, 1988; Jay, 1994).

$\mathrm{Na}$ avaliação microbiológica dos mexilhões in natura para a população de coliformes totais e fecais detectou-se $1,1 \times 10^{2} \mathrm{NMP} / \mathrm{g}$ e 9,3 NMP/g, respectivamente. A contagem de coliformes fecais está dentro do limite da legislação brasileira conforme a portaria $n^{\circ} 451$ do Ministério da Saúde (Brasil, 1997), que estabelece como limite máximo de coliformes de origem fecal em pescado in natura, refrigerado ou congelado, $10^{2} \mathrm{NMP} / \mathrm{g}$. Já, para moluscos bivalves submetidos à cocção e industrializados resfriados ou não, a legislação brasileira, através da resolução no 12 de 02/01/01, da Agência Nacional da Vigilância Sanitária-ANVISA, admite os limites máximos de $5 \times 10 \mathrm{NMP} / \mathrm{g}$ para coliformes fecais e $10^{3} \mathrm{UFC} / \mathrm{g}$ para Staphylococcus coagulase+, estando, portanto, o produto em questão, dentro desses padrões (Brasil, 2005)

Ainda com relação à qualidade microbiológica inicial dos mexilhões, Salmonella e Vibrio parahaemolyticus não foram isolados nas amostras. Quanto 
ao Staphyloocccus coagulase+ o valor encontrado para o mexilhão in natura foi de $7 \times 10^{1} \mathrm{UFC} / \mathrm{g}$, sendo que legislação admite no máximo $10^{3} \mathrm{UFC} / \mathrm{g}$.

Tomando-se como base os padrões microbiológicos vigentes na legislação brasileira, considera-se que os mexilhões utilizados como matériaprima nesta pesquisa, apresentam boas condições sanitárias e estão seguros para o consumo.

A ICMSF - International Commission on Microbiological Standard For Foods (1998) recomenda à indústria de alimentos a utilização de matériasprimas com condições iniciais adequadas, pois falhas no processamento podem determinar a sobrevivência de microrganismos patogênicos de interesse em saúde pública.

Segundo Hobbs et al. (1993), a temperatura acima de $55^{\circ} \mathrm{C}$ é suficiente para destruir células vegetativas de Escherichia coli, Staphylococcus sp e Salmonella sp.

Nesta pesquisa o tratamento térmico aplicado aos mexilhões, de 10 min por imersão em água à ebulição, atingiu temperatura superior a $90^{\circ} \mathrm{C}$. As contagens obtidas no mexilhão após o tratamento térmico para coliformes totais diminuiram de $1,1 \times 10^{2} \mathrm{NMP} / \mathrm{g}$ para 0,9 NMP/g, Staphyloccocus coagulase+ de $7 \times 10^{1} \mathrm{UFC} / g$ para $10^{1} \mathrm{UFC} / g$ e ausência de coliformes fecais após cocção, demonstrando que o processamento térmico utilizado foi eficiente para diminuir e/ou eliminar tais populações de microrganismos.

De acordo com Pigott \& Tucker (1990), os microorganismos patogênicos são destruídos a temperaturas abaixo de $100^{\circ} \mathrm{C}$, sendo que, o efeito de aumentar a temperatura interna dos alimentos para $66^{\circ} \mathrm{C}$ é suficiente para tornar o alimento seguro para o consumo.

A condição inicial dos mexilhões utilizados na etapa de congelamento foi atestada pela ausência de Salmonella, Vibrio parahaemolyticus e reduziu Escherichia coli, após a cocção.

Com o processo de congelamento, houve uma diminuição de 0,9 para 0,4 NMP/g de coliformes totais e redução dos Staphyloocccus 
coagulase+, em níveis não detectáveis, mantendo-se inalterados durante o armazenamento $\mathrm{a}-18^{\circ} \mathrm{C}$ por 90 dias.

De acordo com Jay (1986), as bactérias do grupo coliforme podem crescer a temperaturas de $-2^{\circ} \mathrm{C}$. Porém, temperaturas inferiores a $-5^{\circ} \mathrm{C}$ propiciam um crescimento muito lento. Segundo Olson e Nottingham (1988), microrganismos Gram-negativos, dentre eles Escherichia coli, são mais sensíveis ao congelamento do que os Gram-positivos.

Como pode ser visto na Tabela 6 , a contagem total de psicrotróficos em mexilhão in natura que originalmente foi de $9,3 \times 10^{3} \mathrm{UFC} / \mathrm{g}$, após a cocção foi reduzida em pelo menos 2 ciclos logaritmos. Após o congelamento houve um aumento de 1 ciclo logaritmo na contagem de psicrotróficos e após o armazenamento, uma nova redução de 1 ciclo logaritmo, este detectado após a condução do descongelamento.

Ao final do período experimental, as contagens de bactérias psicrotróficas nos mexilhões estavam abaixo dos níveis usualmente associados com a deterioração do pescado. Realmente, nenhum crescimento bacteriano deveria ser esperado nessas condições. Segundo Huss (1988), a perda da qualidade do pescado ocorre quando as contagens de bactérias aeróbias na pele do peixe alcançam $10^{8}-10^{9} \mathrm{UFC} / \mathrm{g}$.

Os produtos pesqueiros frescos são altamente perecíveis e susceptíveis a deterioração causada pelo crescimento de bactérias psicrotrófilas. A estocagem desses produtos em gelo ou sob refrigeração durante a distribuição e comercialização resulta em pequeno prazo de validade de 5 a 10 dias (Reddy et al., 1996).

Segundo Daudin (1991), as bactérias psicrotróficas do gênero Pseudomonas, principalmente, e outros gêneros predominantes são altamente sensíveis ao congelamento e ao armazenamento.

O congelamento não destrói completamente a microflora do produto, mas o número de células viáveis é reduzido durante o processamento e armazenagem. Imediatamente após o congelamento, a eficiência da eliminação 
de microrganismos varia de acordo com a espécie, sendo que as células que continuam viáveis logo após o congelamento vão, gradualmente, tornando-se inviáveis durante o armazenamento (Sarantopoulos et al., 2001). 


\section{CONCLUSÕES}

O congelamento dos mexilhões apresenta curva de congelamento típica, com ponto de congelamento situando-se na faixa de zero a $-1,5^{\circ} \mathrm{C}$, atingindo cerca de $95 \%$ de água livre congelada. A velocidade de congelamento variou de $2,0 \mathrm{~cm} / \mathrm{h}$ a $3,3 \mathrm{~cm} / \mathrm{h}$ devido à disposição dentro da câmara de congelamento.

Para os padrões de qualidade, os valores BNVT e TMA encontrados nesta pesquisa estão de acordo com as legislações nacional e internacional. Os teores de TBA desmontaram que os mexilhões submetidos à cocção, congelamento e armazenamento congelado por 90 dias mantiveram-se em bom estado de qualidade.

Não houve alteração das características físico-químicas do produto pelo processo de cocção e congelamento.

Todas as amostras de mexilhão in natura atenderam aos padrões microbiológicos estabelecidos pela legislação. $O$ tratamento térmico foi efetivo no controle dos coliformes fecais, bem como na redução das contagens de coliformes totais, Staphylococcus coagulase+ e psicrotróficos.

O mexilhão congelado não apresentou Staphylococcus coagulase+ $\mathrm{e}$ a contagem de coliformes totais foi reduzida com o congelamento.

Esta metodologia do processamento e o monitoramento da qualidade podem ser adotadas pela indústria brasileira para produção de mexilhões congelados. 


\section{REFERÊNCIAS BIBLIOGRÁFICAS}

AL-KAHTANI, H.A.; ABU-TARBOUSH, H.M.; BAJABER, A.S. et al. Chemical changes after irradiation and post-irradiation storage in tilapia and Spanish mackerel. Journal of Food Science, v. 61, n. 4, p.729-733, 1996.

ACKMAN, R.G. Composición y valor nutritivo de los lipídios del pescado y del marisco. In: RUITER, A. El pescado y los productos derivados de la pesca: composición, propriedades nutritivas y estabilidad. Zaragoza: Acribia, 1999. cap. 4. p. 81-121.

ALLEN, C.E.; FOEGEDIND, E.A. Some lipid characteristic and interactions in muscle foods. A review. Food Technology, v.35, p. 253-257, 1981.

AMANAJÁS, C.C. Determinação dos compostos básicos totais de pescado e seu potencial para avaliação do frescor. Campinas, 1985. 78p. Dissertação (Mestrado) - Faculdade de Engenharia de Alimentos e Agrícola, Universidade Estadual de Campinas.

AMERICAN PUBLIC HEALTH ASSOCIATION (APHA). Standard methods for the examination of water and wastewater. 20.ed. Washington, 1998. 937p. 
ANDREWS, W.H.; FLOWERS,R.S.; SILLIKER, J.; BAILEY, J. S. Salmonella. In: VANDERZANT, C. (Ed.). Compendium of methods for the microbiological examination of foods. 4.ed. Washington: American Public Health Association, 1992. cap.25, p.371-415.

ANTONIOLLI, M.A. Vida útil do mexilhão Perna perna (L.) processado e mantido sob refrigeração. Florianópolis, 1999. 99p. Dissertação (Mestrado) Universidade Federal de Santa Catarina.

ARDITO, E.F.G.,ALVES, E.M.V. Embalagens para alimentos congelados. Coletânea do Instituto Tecnológico de Alimentos, v. 24, n.1, p.11-28, 1994

ASSOCIAÇÃO CATARINENSE DE AQUICULTURA - ACAQ. Valores nutricionais do mexilhão Perna perna e da ostra Crassostre gigas. http://www.acaq.org.br/valores_nutricionais.htm (6 dez 2004).

ASSOCIATION OF OFFICIAL AGRICULTURAL CHEMISTS. Official methods of analysis. $16 \mathrm{ed}$. Washington, 1995. v. 2. 1250 p.

ASSUMPÇÃO, A. Estudo da viabilidade de criação de cooperativa dos produtores de mexilhões do Litoral Norte paulista. Piracicaba: ESALQ, Departamento. Economia, Administração e Sociologia, 1999. 40 p. (Relatório CES, 629).

AYRES, J. C. Ocorrence of enterococci and coliform organisms on fresh and stored poultry. Food Technology, n. 15, p. 92-286, 1961. 
BEIRÃO, H.; TEIXEIRA, E.; MEINERT, E.M.; Processamento e industrialização de moluscos. In: SEMINÁRIO E WORKSHOP TECNOLOGIAS PARA APROVEITAMENTO INTEGRAL DO PESCADO. Campinas, 2000. Campinas: ITAL, Centro de Tecnologia de Carnes, p.38-84.

BEN, A.M. Effect of freezing and microbial growth on myoglobin derivates of beef. Food Chemistry, v. 147, n. 10, p. 4093, 1999.

BENNETT, A.R.;MACPHEE, S.; BETTS, R.; POST, D. Use of pyrrolidonyl peptidase to distinguish Citrobacter from Salmonella. Letters in Applied Microbiology, v.28, p.175-178, 1999.

BERTULLO, V. Tecnologia de los productos y subproductos de pescados, moluscos y crustaceos. Buenos Aires: Ed. Hemisferio Sur, 1976. 370p.

BORGHETTI, J.R.; OSTRENSKY, A. A cadeia produtiva da aqüicultura brasileira. In: VALENTI, W.C.; POLI, C.R.; PEREIRA, J.A.; BORGETTI, J.R. Aqüicultura no Brasil. Brasília: CNPQ, 2000. p. 73-106.

BRANDINI, F.P.; SILVA, S.S.;PROENÇA, L.A.O. Oceanografia e maricultura. In: VALENTI, W.C.; POLI, C.R.; PEREIRA, J.A.; BORGETTI, J.R. Aqüicultura no Brasil. Brasília: CNPQ, 2000. p. 107-142.

BRASIL. Ministério da Agricultura. Regulamento da Inspeção Industrial e Sanitária de Produtos de Origem Animal - R.I.I.S.P.O.A. Brasília, 1980. $165 p$. 
BRASIL. Ministério da Agricultura, Pecuária e Abastecimento e Secretaria Nacional de Defesa Agropecuária. Laboratório Nacional de Referência Animal. Métodos analíticos oficiais físico-químicos para controle de pescado e seus derivados. Brasília, 1981. cap.5, p.1-3: Métodos quantitativos.

BRASIL. Ministério da Agricultura e Abastecimento. (MAPA) http://www.agricultura.gov.br. (20 abr.2004)

BRASIL. Ministério da Agricultura, Pecuária e Abastecimento. Regulamentos técnicos de identidade e qualidade de leite e produtos lácteos. Ministério da Agricultura e do Abastecimento/Secretaria da Defesa Animal/Departamento de Inspeção de Produtos de Origem Animal/Divisão de Normas Técnicas. Brasil, D.F. Série regulamentação técnica de identidade e qualidade de produtos de origem animal; n.2. 1997. 77p.

BRASIL. Ministério da Saúde. Agencia Nacional da Vigilância Sanitária. Resolução - RDC n¹2, de janeiro de 2001. Regulamento técnico sobre padrões microbiológicos em alimentos. http://www.anvisa.gov/legis//resol. (25 jan. 2005)

BRYAN, F. L. Activities of the center for disease control in public health problems related to the consumption of fish and fishery products. In: CHICHESTER, C. O.; GRAHAM, H. D. Microbial safety of fishery products. New York: Academic Press, 1973. p. 275-301.

CARNEIRO, M.J.M.; Congelamento de filés de sardinha por imersão e avaliação física e sensorial de sua qualidade durante a estocagem. Campinas, 1999.135 p. Tese (Doutorado) - Faculdade de Engenharia de Alimento, Universidade Estadual de Campinas. 
CLAVERIE, I. Inspeccion sanitária y control de áreas de crescimento de moluscos bivalvos. Anexo al informe del eminário sobre nspeccion y control de calidad de oluscos bivalves. Santiago: Oficina Regional FAO para America Latina y el Caribe, 176p. 1986.

CLUCAS, I. J. Fish handling, preservation and processing in the tropics. London: Tropical Products Institute, 1981. v.1. 85p.

CONTRERAS-GUZMAN, E.S. "Pescado e produtos" marinhos". In: VAN DENDER, A.G.F. Armazenamento de gêneros e produtos alimentícios. São Paulo: Secretária de Indústria e Comércio, Ciência e Tecnologia, 1982. p.201-225.

DAUDIN, J.D. La congelación. In: GIRARD, J. P.(Ed). Tecnologia de la carne y de los productos cárnicos. Zaragoza: Acribia. 1991. p.1-33.

El-KEST, S.E.; MARTH, E.H. Freezing Listeria monocytogenes and other microorganisms: a review. Journal of Food Protection, v.55, p. 639-648, 1992.

ESPÍNOLA, O.; DIAS, R.R.C. O mexilhão como matéria-prima alimentar. ABIA/SAPRO, n.47, p.10-30, abr. 1980.

FOOD AND AGRICULTURE ORGANIZATION-FAO World fisheries production by capture and aquaculture, by country. http://www.fao.org/fi/statis/summ-99/aqua-a.0.pdf (3 Dec. 2003)

FENNEMA, O.R. Preservation of food by storage at chilling temperatures. In: KAREL, M.; FENNEMA, O R; LUND, D.B. Physical principles of food preservation. New York: Marcel Dekker, 1975. p.133. 
FRANCO, B. D. G. M.; LANDGRAF, M. Microbiologia dos alimentos. São Paulo: Atheneu, 1996. 182 p.

FRAZIER, W. C.; WESTHOFF, D. C. Microbiologia de los alimentos. 4 ed. Zaragoza: Acribia, 1993. p.325-339.

FURLAN, E.F. Vida útil dos mexilhões Perna perna cultivados no litoral norte de São Paulo: aferição dos parâmetros físico-químicos e microbiológicos. Piracicaba, 2004. 108p. Dissertação (Mestrado) - Escola Superior de Agricultura "Luiz de Queiroz" Universidade de São Paulo.

FURTADO, S.M.B.; DOMINGOS, T.H.; SOARES, A.K. Determinação da composição centesimal e minerais de moluscos (Mytella falcata e Anomalocardia brasiliana) mais consumidos no estado do Rio Grande do Norte (Compact disc) CONGRESSO BRASILEIRO DE CIENNCIA E TECNOLOGIA DE ALIMENTOS, 16., Porto Alegre, 1998. Resumos. Porto Alegre: UFRS, 1998.

FURTADO, A.A.L. Conservação de frutos do mar. In: SEMINÁRIO E WORKSHOP TECNOLOGIA PARA APROVEITAMENTO INTEGRAL DO PESCADO. Campinas: Centro e Tecnologia de Carnes. Campinas: ITAL, 2000. p.7-12.

GELLI, V.C. Aproveitamento de mexilhões - aspectos gerais MolluscaBivalvia.(monografia). Fortaleza: Universidade Federal do Ceará, 1992. 98p.

GEROMEL, E.J.; FORSTER, R.J. Princípios fundamentais em tecnologia de pescados. São Paulo: Secretaria da Indústria, Comércio, Ciência e Tecnologia e Coordenadoria da Indústria e Comércio, 1982. 127p. 
GRAHN, J.Intalling an air blest freezer. Torry Advisory Note,35, 16p. s.d

GRAY, J.I.; GOMAA, E.A; BUCKELEY, D.J. Oxidative quality and shelf life of meats. Meat Science, v. 43, p.111-123, 1996.

HALÁSZ, L.; PINHEIRO, C.P.; ARAUJO FILHO, E. N.; SATO, G.T.; YOSIMURA, I.Y.; TAYAR, Y.; LACERDA, R. Refrigeração. São Paulo: Secretaria da Indústria, Comércio, Ciência e Tecnologia. Coordenadoria da Indústria e Comércio. 1982. 200p.

HANSEN, P. Fish preservation methods. In: CONNELL, J.J. Advances in fish science and technology. London: Fishing News Books, 1980. p.28-34.

HITCHINS, A.D.; FENG, P.; WATKINS, W.D.; ROPPEY, S.R.; CHANDLER, L.A. Escherichia coli and the Coliform bacteria. http://www.cfsan.fda.gov (14 Oct. 2004).

HOBBS, B.C., ROBERTS, D.; NASCIMENTO, M.A. Toxinfeccões e controle higiênico-sanitário de alimentos. São Paulo: Varela, 1993. 376p.

HUNGERFORD, J. M. Fish and other marine products. In: ASSOCIATION OFFICIAL AGRICULTURAL CHEMISTS (A.O.A.C.). Official methods of analysis. Washington, 1995. cap.35, p.1-30.

HUSS, H.H. Fresh fish: quality and quality changes. Roma: FAO/DANIDA, 1988. p. $43-45$.

INSTITUTO INTERNACIONAL DEL FRIO. Alimentos congelados-procesado y distribuición. Zaragoza: Acribia, 1990. 184p. 
INTERNATIONAL COMMISSION ON MICROBIOLOGICAL STANDARD FOR FOODS. Microorganisms in foods- application of the hazard analysis and critical points system to ensure microbiological safety and quality. Oxford, 1988. v.4. 357p.

INTERNATIONAL COMMISSION ON MICROBIOLOGICAL STANDARD FOR FOODS (ICMSF). Microorganisms in foods. Microbial ecology of food commodities. London: Blackie Academic and Professional, 1998. p.154158: Fish and fish products. INSTITUTO BRASILEIRO DO MEIO AMBIENTE E DOS RECURSOS
NATURAIS
RENOVÁVEIS http://www.ibama.gov.br/cepene/paginas/pg.php?id_arq=68 (14 jun. 2005)

JAY, J.M. Modern food microbiology. 3 ed. New York: Van Nostrand Reinhold, 1986. 642p.

JAY, J.M. Microbiologia moderna de los alimentos. 3. ed. Zaragoza: Acribia, 1994. 804p.

KANNER, J. Oxidative processes in meat and meat products: quality implications. Meat Science, v.36, n.1/2, p.169-189, 1994.

KARAÇAM, H.; BORAN, M.; Quality changes in frozen whole and gutted anchovies during storage at $-18^{\circ} \mathrm{C}$. International Journal of Food Science and Technology, v.31, p.527-531, 1996.

KAREL, M. Physical principles of food preservation. Madison: CRC Press, 1975, cap.10, p.309-358: Dehydration of foods. 
KIROV, S.M.; ARDESTANI, E.K.; HAYWARD, L.J. The growth and expression of virulence factors at refrigeration temperature by Aeromonas strains isolated from foods. International Journal of Food Microbiology, v. 20, p. 159-68, 1993.

LABUZA, T.P. Shelf-life dating foods. Chicago: Food \& Nutrition Press, 1982. cap. 10. p.359-372: Basic food preservation and degradation modes.

LAKSHMANAN, P. T., VARMA, P.R., IYER, T. S. G. Studies on the quality changes of frozen fish in retail cold stores. Food Science Technolology , v. 24, n.2, p.190, 1992.

LANCETTE, G.A.; TATAINI, S.R. Staphylococcus aureus. In: DOWES, F.P.; ITO, K. (Ed.). Compendium of methods for the microbiological examination of foods. 4.ed. Washington: American Public Health Association, 2001. p.387-403.

LUNETTA, J.E., Florescimento da mitilicultura no Brasil. In: SIMPÓSIO DE BIOLOGIA MARINHA, 17., São Sebastião, 2002. Resumos. São Sebastião: CEBIMar/USP, 2002.

MAGALHÃES, A.R.M. Teor de proteína do mexilhão Perna perna (Linné, 1957) (Molusca - Bivalvia) em função do ciclo sexual. São Paulo, 1986. 117p. Dissertação (Mestrado). Instituto de Biociências, Universidade de São Paulo.

MANOUSARIDIS, G.; NERANTZAKI, A.; PALEOLOGOS, E.K.; TSIOTSIAS, A.; SAVVAIDIS, I. N.; KONTOMINAS, M.G. Effect of ozone on microbial, chemical and sensory attributes of sucked mussel. Food Microbiology, v. 22. n.1. p.1-9, 2005. 
MARTINEZ-MANZANARES, E.; MORINIGO, M. A.; CORNAX, R; EGEA, R.; BORREGO. J. J. Relation between classical indicators and several pathogenic microorganismos involved in shellfish-borne diseases. Journal of Food Protection, v. 54, n. 9, p. 711-717, 1991.

McDONALD, I. Freezing small pelagic fish. Torry Advisory Note, n. 75, p.1-8, s.d.

MILLS, A. Measuring changes that occur during frozen storage of fish: a review. Journal of Food Technology, v. 10, n. 5, p. 483-496, 1975.

MESSER, J.W; MIDURA, T.F; PEELER, J.T. Sampling plans.In: VANDERZANT, C.; SPLITTSTOESSER, D. F. Compedium of methods for the microbiological examination of foods. 3.ed. Washington: American Public Health Association, 1992. cap.2, p.25 -74.

MORRIS, D.M.; DAWSON, L.E. Storage stability of mechanically deboned sucher (Castostomidae) flesh. Journal of Food Science, v.44, n.4, p. 10931096, 1979

NEIVA, C.R.P. Valor agregado $x$ qualidade do pescado. www.pesca.sp.gov.br/textos.php (15 nov. 2003).

NETTO, F.M. Modificações químicas, bioquímicas e sensoriais do híbrido de tilápia estocado em gelo. Campinas, 1984. 79p. Dissertação (Mestrado) Faculdade de Engenharia de Alimentos, Universidade Estadual de Campinas.

NEVES FILHO, L.C.; Resfriamento, congelamento e estocagem de alimentos. São Paulo: IBF/ABRAVA/SINDRATAR, 1991. 176p. 
OETTERER, M. Industrialização do pescado cultivado. Guaíba: Editora Agropecuária, 2002. 200 p.

OETTERER, M. Diagnóstico e intervenções emergentes para viabilizar a comercialização e o beneficiamento do pescado e derivadosmexilhões, no Litoral Norte de São Paulo. São Paulo: FAPESP, s.d. (Relatório da $1^{\text {a }}$ fase do projeto de políticas públicas da FAPESP - Processo $01 / 12919-1.2003)$.

OGAWA, M.; MAIA, E.L. Manual de pesca: ciência e tecnologia do pescado. São Paulo: Varela, 1999. 430p.

OLSON, J.C., NOTTINGHAM, P.M. Temperatura. In: INTERNATIONAL COMISSION ON MICROBIOLOGICAL SPECIFICATIONS FOR FOODSICMSF (Ed). Ecologia microbiana de los alimentos: productos alimenticios. Zaragoza: Acribia, 1988. p.1-38.

PACHECO, D. Brasil investe no futuro da aqüicultura e pesca. Revista Nacional da Carne, v. 28, n. 326, p.18-23, 2004.

PAINE, F.A.; PAINE, H.Y. A handbook of food packing. Glasgow: Blackie Academic \& Professional, 1983. 497p.

PEREIRA, C.S.; POSSAS, C.A.; VIANA. C.M.; RODRIGUES, D.P. Aeromonas spp. e Plesiomonas shigelloides isoladas a partir de mexilhões (Perna perna) in natura e pré-cozidos no Rio de Janeiro, RJ. Ciência e Tecnologia de Alimentos. v.24, n.4, p.562-566p, 2004. 
PIGOTT, G.M.; TUCKER, B.W. Seafood- effects of technology on nutrition. New York: Marcel Dekker, 1990. p. 104- 135.

PLANK, R. Empleo del frio en la industria de la alimentacion. Barcelona: Editorial Reverté, 1963. 805p.

PORRELLI, P.;GALVÃO J.A; FURLAN, E.F. et al. Interferência das características biométricas na composição centesimal de mexilhões Perna perna (L). In: SIMPÓSIO INTERNACIONAL DE INICIAÇÃO CIENTÍFICA DA UNIVERSIDADE DE SÃO PAULO, 11, Piracicaba, 2003. Anais. Piracicaba: Escola Superior de Agricultura “Luiz de Queiroz”, 2003.

PREGNOLATTO, W.; PREGNOLATTO, N. P. Normas analíticas do Instituto Adolfo Lutz. São Paulo: Instituto Adolfo Lutz, 1985. v.1, 533p.

REDDY, N. R.; PARADIS, A. ROPMAN, M. G.; SOLOMON, H. M.; RHODEHAMEL, E. J. Toxin development by Clostridium botulinum in modified atmosphere-packaged fresh tilapia fillets during storage. Journal of Food Science, v. 61, n. 3, p. 632-635, 1996.

REGENSTEIN, J. M.; SCHLOSSER, M. A.; SAMSON, A.; FEY, M. Chemical changes of trimethylamine oxide during fresh and frozen storage of fish. In: MARTIN, R.E.; FLICK, G. J.; HERBERD, C.E.; WARD, D. R (Ed). Chemistrry \& biochesmitry of marine food products. Westport: Avi Publishing, 1982. p.137-147.

ROBERTSON, G. L. Food packaging: principles and pratice. New York: Marcel Decker, 1992. 676p. 
SACCONI, A.J.P. Estocagem e transporte de pescado congelado. In: SEMINÁRIO SOBRE CONTROLE DE QUALIDADE DO PESCADO. Santos, 1988. Anais. Santos: Editora Leopoldina, Loyola, 1988. p.289-295.

SALAN, E. O. Tratamento térmico de mexilhões Perna perna como forma de assegurar a qualidade - avaliação do crescimento de Bacillus cereus e de Staphylococcus aures. Piracicaba, 2005 88p. Dissertação (Mestrado) Escola Superior de Agricultura “Luiz de Queiroz" Universidade de São Paulo.

SANT'ANA, L.S.; FERNANDES, J.B. Efeito do armazenamento na composição em ácidos graxos de filés de peixes da espécie pacu (Piaractus mesopotamicus). In: CONGRESSO BRASILEIRO DE CIENCIAS E TECNOLOGIA DEALIMENTOS, 17.,Fortaleza, 2000, Resumos. Fortaleza: Sociedade Brasileira de Ciências e Tecnologia de Alimentos, 2000. v.4. p.5-272.

SARANTÓPOULOS, C. I. G. L.; OLIVEIRA, L. M.; CANAVESI, E. Requisitos de conservação de alimentos em embalagens flexíveis. Campinas: CETEA/ITAL, 2001. 213p.

SAS Institute. SAS user's guide: statistics (software). Version 8.0. Cary: SAS, 1999.

SCHORMULLER, J. Lehrbuch der lebensmittelchemie. Berlin: SpringerVerlag, 1974. 829p.

SCHRAMM, M.A. Caracterização e aproveitamento de mexilhões Perna perna (Linné, 1758). Porto Alegre: Faculdade de Engenharia de Alimentos, Universidade do Rio Grande do Sul, 1993. 54p. 
SCORVO FILHO, J.D. Panorama da aqüicultura. http://www.acaq.org.br/arquivos (14 set 2004).

SILVA, N. da; JUNQUEIRA, V.C.A; SILVEIRA, N.F. de A Manual de métodos de análises microbiológicas de alimentos. São Paulo: Varela, 1997. $295 p$.

SILVA, J.A. Tópicos da tecnologia dos alimentos. São Paulo: Varela, 2000, $227 p$.

SILVA JUNIOR, E.A. Manual de controle higiênico-sanitário em alimentos. São Paulo:Varela, 1995. 347p.

SIKORSKI, Z.E.; KOTAKOWSKA, A. Changes in proteins in frozen stored fish. In: SIKORSKI, Z.E.; SUN PAN, B.; SHAHDIDI, F. Seafood protein. New York: Chapman \& Hall, 1994, p.99-112.

SIMÕES, A.C. Instituto de pesca promove a aqüicultura. http://www.pesca.sp.gov/arquivos/artigos (5 nov 2005)

SON, N.T.; FLEET, G.H. Behavior of pathogenic bacteria in the oyster, Crassostrea commercialis, during depuration, re-laying, and storage. Applied and Environmental Microbiology, v. 40, n. 6, p. $994-1002.1980$.

SOUDAN, F. La conservation par lê froid dês poissons, crustacés et mollusques. Paris: J. B. Baiilliére et Fils, 1965. 514p.

TAKANO, M.; SIMBOL, A.B.; YASINUM, M.; SHIBASAKI, I. Bactericidal effectes of freezing with chemical agents. Journal of Food Science, v.44 p.112-115, 1979. 
TARLADGIS, B.G.; WATTS, B.M.; YOUNATHAN, M.T.A. A distillation method for the quantitative determination of malonaldehyde in rancid foods. Journal American Oil Chemist's Society, v.37, n. 1, p.44-48, 1960.

TAVARES, M.; AMARAL MELO, M.R.P.; CAMPOS, N.C. et al. Proximate composition and caloric value of the mussel Perna perna, cultivado em Ubatuba, estado de São Paulo, Brasil. Food Chemistry, v.62, n.4, p.473475, 1998.

TAVARES, M.; SABRIA, A.; BACETTI, L.B. Métodos sensoriais, físicos e químicos para análise de pescado. In: SEMINÁRIO SOBRE CONTROLE DE QUALIDADE NA INDÚSTRIA DE PESCADO. Santos, 1988. Anais. São Paulo: Instituto de Pesca, 1988. p.117 -134.

UNITED STATES DEPARTMENT OF AGRICULTURE - USDA. Base de dados de nutrients. http://www.unifesp.br/dis/servicos/nutri. (15 Jan. 2005)

VAN LAACK, R.L.J.M. Spoilage and preservation of muscle foods. In: KINSMAN, D. M.; KOTULA, A. W.; BREIDENSTEIN, B.C. Muscle foods. New York: Chapman and Hall, 1994. cap.14, p.378-405.

WEST, P.A. The human pathogenic vibrios - A public health update with environmental perspectives. Epidemiology and Infection, v.103, p.1-34, 1989.

WOOD, P.C. Manual de higiene de los mariscos. Zaragoza: Acribia, 1979. 83p. 